\title{
Biofouling and Biocorrosion in Industrial Water Systems
}

\author{
S. E. Coetser and T. E. Cloete
}

\section{INTRODUCTION}

When water-borne bacteria congregate in sufficient numbers they form a film on the surface of pipes, tanks, and indeed any piece of equipment. This "biofilm" consists of mainly water, bacteria, suspended solids, corrosion products, algae, yeasts/molds, protozoa, and molluscs. Biofilm cause the deterioration in the microbiological quality of water by inducing biocorrosion and biofouling. The corrosion and weathering caused by this biofilm can lead to considerable damage, ranging from contamination of pharmaceutical or microelectronic products, to reduced efficacy of heat exchangers, unexpected corrosion of stainless steel, and premature destruction of mineral materials.

Many bacteria are planktonic, which means that they float around in water. However the bulk of the bacteria that cause problems are sessile - attached to a surface.

Once bacteria attach to a surface they go through a series of changes, the most obvious of which is the excretion of a slimy material, referred to as biofilm. Linked to this is the problem that when bacteria attach to a surface, a whole different suite of genes is activated, making sessile bacteria significantly different to planktonic bacteria suspended in the water.

Industrial process water or potable water is not sterile, so there is biofilm in all systems that are inherently present without causing problems.

Problems occur when the biofilm builds up ("biofouling"), creating dead biomass and therefore a nutrient source that leads to re-growth of organisms in the water.

Biofilm structures vary according to flow conditions in a water system, for example, a turbulent flow produces homogenous and slimy biofilms, which are harder to "inactivate" than biofilms produced by laminar flows. Also, the effectiveness of a disinfectant or biocide depends on the age of the biofilm as well as its particular physical and chemical structure.

The present trend in industrial water systems is to minimize both water consumption and water discharge by recirculation. This results in the concentration of dissolved and suspended substances promoting growth of waterborne microbes, and shifting the microbial community to a more copiotrophic state.

The accumulation of undesirable organic materials on any surface either natural or man-made is generally referred to as biofouling with subsequent macrofouling of the system and concomitant microbially induced corrosion.

Microorganisms always live in an aqueous environment whether it is in the film of water around a soil particle in the blood of a mammalian host or in lake water (Hobbie \& Fletcher 1988). Bacteria all require water in their immediate surroundings (VanDemark \& Batzing 1987). The microbial habitat is an aqueous one. Each bacterial species has a certain degree of adaptability and can grow in a different niche (Atlas \& Bartha 1987). Actually, all bacteria are water organisms. However, water in the strict sense of habitat is water visible to the naked eye, a habitat termed the hydro-ecosphere (Atlas \& Bartha 1987b). The hydro-ecosphere includes lakes, dams, rivers, temporary ponds, estuaries, and the open oceans that contain $97 \%$ of the Earth's water (Grant \& Long 1981). Consequently, most bacteria are adapted to such aqueous environments and can be expected to proliferate there. It is not surprising, therefore that industrial water systems carry such large quantities of bacterial biomass. The most important environment in flowing waters is the surface micro-environment (Hobbie \& Fletcher 1988). It is protective and offers resident bacteria a nutritional advantage so that surfaces are the major site of microbial activity (Van Loosdrecht et al. 1990). Harvey and Young (1980) showed that almost all bacteria involved in mineralization of estuarine carbon were associated with particles. Kirchman and Mitchell (1982) found the contribution of particle-bound bacteria to total heterotrophic activity to be four times as high as expected from the fraction of attached cells. Many aquatic bacteria depend on attachment to surfaces for survival with sessile cells growing and dividing at nutrient concentrations too low to permit growth in the planktonic phase (Kjelleberg et al. 1982). Consequently, most surfaces exposed to water are covered in bacterial conglomerates termed biofilms (Lewin 1984) Bacteria in natural systems seldom if ever, occur in pure culture. They form part of food chains and many are only found as part of consortia and never on their own (Costerton etal. 1987). Bacterial consortia are often highly structured (Costerton et al. 1987), catalysing breakdown of complex substrates to $\mathrm{CO}_{2}$. Bacteria as members of biofilms benefit in various ways. They have enhanced access to nutrients, are close to cells with which they are in mutalistic or synergistic relationship and are protected to a high degree from various antimicrobial mechanisms, i.e., biocide, antibiotics, antibodies and predators (Costerton \& Lappin-Scott. 1989).

\section{MICROBIAL ATTACHMENT TO SURFACES}

In order to remain in the proximity of a surface, bacteria must adhere or attach. Marshall (1984) proposed the term adhesion, 
defining it as follows: "Adhesion can be defined unambiguously only in terms of the energy involved in the formation of the adhesive junction. Thus two surfaces may be said to have adhered when work is required to separate them to their original condition." Physically speaking, adhesion is an example of particle adsorption on a substrate (Rutter \& Vincent 1988). Bacteria usually carry a net negative charge, and so do the surfaces to which they absorb (Van Loosdrecht et al. 1990). They can further be considered colloidal particles, though they are not inert and can change characteristics with altering environment (Van Loosdrecht et al. 1990).

Various authors have expanded on the physicochemical thermodynamic approach, including Absolom et al. (1983), Rutter and Vincent (1984), and Van Loosdrecht et al. (1989). Absolom et al. (1983) employed a concept of short-range interaction. Bacteria are seen to be in direct contact with the substratum and the Gibbs free energy is estimated from the interfacial tension. Alternatively, the contact angle can be used. Rutter and Vincent $(1984,1988)$ used the long-range interaction concept based on the DLVO (Derjaguin and Landau, and Verwey and Overbeek) theory for colloidal stability. Here the interaction Gibbs free energy between particle and surface is a function of the distance between the two. As both bacteria and surface usually carry a net negative charge there is a net repulsive interaction between cells and surface (Van Loosdrecht et al. 1989).

Other authors have taken an empirical approach, observing attachment microscopically, and modeling the adsorption process thereon. Among them are Characklis (1983), Costerton et al. (1987), Hamilton (1987), Bryers (1988), and Wolfaardt and Cloete (1992). Attachment is usually studied by image analysis of video signals of thin flow cells. The most important technique described to date is image analysis of images obtained by con-focal laser microscopy developed by Caldwell and Lawrence (1989). Hamilton (1987) argued that new surfaces in aqueous surroundings adsorb organic molecules, resulting in a so-called conditioning film. Bacteria can then attach to this layer and not to the metal surface.

\section{DEVELOPMENT OF BIOFILMS}

Lawrence et al. (1987) described the mechanics of attachment of Pseudomonas fluorescence to surfaces in the hydrodynamic environment: motile cells move down and upstream even against a laminar flow velocity. At this stage, some detach and reattach elsewhere. After 2 min. rotation slows and ceases and the cell becomes attached along its longitudinal axis. Extra cellular polymers are produced, which fill the area between cell and surface and attach the cell irreversibly (Lewin 1984; Costerton \& Lappin-Scott 1989). Attached cells grow and divide, sliding in next to each other in an obliquely adjacent position (Lawrence et al. 1987). Some members of the microcolony then start a vibrational movement, which leads to some cells leaving the surface (Lawrence et al. 1987; Figure 25.1).

Cells in the microcolonies produce extracellular polymers (EPS) (Costerton et al. 1987). Costerton et al. (1981) termed EPS, whether capsule or a loose network, as a glycocalyx. The bacterial cell is at a set distance from the surface, depending solely on the radius of curvature, and protrusions such as flag-ella, pili, and loose strands of EPS can penetrate the energy barrier (Lewin 1984). EPS are complex polymers, which vary not only between isolates, but also under different culture conditions (Sutherland 1985; Whitfield 1988).

As the surface is covered, lateral interactions between particles must be taken into account. If adsorbing particles are all of the same type, lateral interactions will be repulsive at low electrolyte concentrations, but attractive at high ones (Rutter \& Vincent 1984). Electrolytes actually decrease the repulsive effect of the electrical double layer sufficiently by changing the surface charge of particles.

Parameters affecting the development of biofilms:

- Ambient and system temperatures that is related to season, day length, climate, and wind velocity.

- Water flow rate past the surface

- Nutrient availability.

- Roughness or the surface material.

- An approximately neutral $\mathrm{pH}$ of the water is optimal for the growth or most biofilm-forming bacteria.

- Particulate matter can become entrapped in the developing biofilm and provide additional attachment sites.

- Effectivity of biofouling control measures.

The primary colonisers are mainly Pseudomonas species as they attach well and possess polar flagella (Wolfaardt 1990). During biofilm development, considerable amounts of EPS material are synthesized such that the mature biofilm contains only $10 \%$ or less of its dry weight in the form of cells (Hamilton 1985). Oxygen in the film is depleted by respiration. Young biofilms contain few species, reflecting the low diversity of pioneer populations (Atlas 1984), but diversity increases to form a stable climax community. Diversity is always underestimated due to the selectivity and inadequacy of pure-culture isolation techniques (Brözel 1990).

Sessile bacteria have different properties to those of planktonic or agar-grown bacteria. They exhibit a different metabolism, and are often highly dependent on other members of the consortium (Costerton et al. 1986). Much information has been published on the planktonic bacteria. Yet these constitute less than 0.1\%ormost ecosystems (Costerton et al. 1986). Valeur et al. (1988) showed that free-living Gram-negative bacteria had different membrane lipid composition and a much higher poly-hydroxybuty 
rate (PHB) content than attached bacteria.

As the biofilm develops, various gradients develop across it, as exchange of substances (nutrients and gasses) only occurs on one side (Characklis 1983). A nutrient gradient develops, with respiration at the upper layer and fermentation in the middle layer (Pfennig 1984). An oxygen gradient also develops, due to respiration of bacteria in the upper layer (Hamilton 1987). When the biofilm has reached a thickness of 10-25 micrometer, conditions at its base are anaerobic (Hamilton 1987). The biofilm is now approaching a state of maturity, with a high species diversity and consequent stability (Hamilton 1987).

The formation of biofilms is of considerable importance in the food industry where attached bacteria on surfaces in food processing plants are a potential source of food contamination. Biofilms develop and survive sterilization in dead ends of pipelines in liquid food processing plants and act as a point of contamination of the sterilized product.

When a metal is exposed to natural waters, corrosion begins immediately. In some cases microorganisms influence the corrosion process. The corrosion of metal and the composition of the corrosion deposits largely depend on microbiology, metallurgy, electrochemistry, and bulk water chemistry (Borenstein 1994).

\section{Abiotic (Electrochemical) Corrosion}

Corrosion is an electrochemical phenomenon in which the electrical potentials of two adjacent areas of a metallic surface within a conductive medium differ relative to each other, such that one area is anodic and the other cathodic (Barton 1997; Hamilton 1985). Metals are usually found in nature in their oxidised state, with the exception of some of the noble metals, which may occur in the elementary state (Brözel 1990). However, metals used in the man-made structures of today exist in a state of high energy, which easily reverts in the presence of a suitable electron acceptor (Brözel 1990). Corrosion is common to all base metals in aqueous, or at least humid, environments (De Bruyn 1992).

Metal dissolution takes place at the anodic sites (Hamilton 1985; Barton 1997):

$$
\mathrm{M} \rightarrow \mathrm{M}^{2+}+2 \mathrm{e}
$$

The electrons are accepted in a cathodic reaction at separate sites (Hamilton 1985). Oxygen is most commonly involved in the reaction at the cathode and occurs at neutral or alkaline $\mathrm{pH}$ values (Hamilton 1985; Barton 1997):

$$
1 / 2 \mathrm{O}_{2}+\mathrm{H}_{2} \mathrm{O}+2 \mathrm{e} \rightarrow 2 \mathrm{OH}^{-}
$$

However, under acid conditions, protons may be the cathodic reactant,

$$
2 \mathrm{H}^{+}+2 \mathrm{e} \rightarrow 2 \mathrm{H}+\mathrm{H}_{2}
$$

giving rise, first to atomic then to molecular hydrogen (Hamilton 1985).

The products of the anode and cathode processes usually react to yield corrosion products, as in the case of iron:

$$
\mathrm{Fe}^{2+}+2\left(\mathrm{OH}^{-}\right) \rightarrow \mathrm{Fe}(\mathrm{OH})_{2}(\text { Iverson 1987) }
$$

Ferrous hydroxide is converted to ferric hydroxide in the presence of additional oxygen, which precipitates as hydrous ferric oxide $\left(\mathrm{Fe}_{2} \mathrm{O}_{3} \cdot \mathrm{H}_{2} \mathrm{O}\right)$, a form of rust (Iverson 1987).

$$
\mathrm{Fe}(\mathrm{OH})_{2}+1 / 2 \mathrm{H}_{2} \mathrm{O}+1 / 4 \mathrm{O}_{2} \rightarrow \mathrm{Fe}(\mathrm{OH})_{3}
$$

Ultimately, the rust deposited on steel consists of three layers of iron oxides at different stages of oxidation (Lee et al. 1995). The innermost adherent layer is largely greenish ferrous hydroxide $\left(\mathrm{Fe}(\mathrm{OH})_{2}\right)$; the outer layer consists largely of orange ferric hydroxide $\left(\mathrm{Fe}(\mathrm{OH})_{3}\right)$, while magnetite $\left(\mathrm{Fe}_{3} \mathrm{O}_{4}\right)$ forms a black intermediate layer between the ferrous and ferric hydroxides.

The corrosion products form loose films or very thin, slightly adhesive protective films, which decrease the rate of corrosion (De Bruyn 1992). The anodic and cathodic reactions must remain in balance and the electrolytic cell must continue functioning over prolonged periods in order for corrosion to proceed (DeBruyn 1992).

\section{Microbiologically Influenced Corrosion (MIC)}

Microbial activity may induce or enhance corrosion reactions (Ford \& Mitchell 1990). The deterioration of a material, usually a

metal, by processes which occur, either directly or indirectly, as a result of bacterial activity may be defined as microbial induced corrosion (MIC) (De Bruyn 1992; Iverson 1987). MIC is also known as biological corrosion, biologically induced corrosion and bio corrosion (Borenstein 1994).

MIC constitutes approximately $10 \%$ of all metallic corrosion (Brözel \& Cloete 1989). In South Africa alone the direct cost of 
MIC has been estimated at around R400 m per annum, and at 16 to 17 billion US dollars per annum in the USA (Brözel \& Cloete 1989).

Two distinct classes of microorganisms cause corrosion, the aerobic and anaerobic groups with distinctly different types of corrosion reactions (Von Holy 1985). The classic corrosion reaction is electrochemical and remains valid for MIC (Ford \& Mitchell 1990; De Bruyn 1992). However, the involvement of microorganisms in this process has been difficult to evaluate (Ford \& Mitchell 1990). Due to the fact that corrosion processes are almost always complex, involving several possible reactions, there are practical difficulties associated with the unequivocal identification of MIC in many field situations (Hamilton 1985). There are a variety of environmental factors, which obstruct the study of corrosion mechanisms (Lee et al. 1995). These reactions are therefore not mutually exclusive but instead can act in concert.

The anodic and cathodic reactions must remain in balance and the electrolytic cell must continue functioning over prolonged periods for corrosion to proceed to a significant extent (Hamilton 1985). Under aerobic conditions, these conditions are met by the continuous supply of oxygen to the cathode and by the removal of insoluble iron oxides and hydroxides at the anode (Hamilton 1985). The role of the microorganisms is either to assist in the establishment of the electrolytic cell (indirect) or to stimulate the anodic or cathodic reactions (direct) (Hamilton 1985).

According to Cloete and Flemming (1997), microorganisms influence corrosion in a number of ways:

- Utilisation of oxygen by aerobic organisms resulting in anodic areas. Localised differences in concentration shift the potential of metal surfaces resulting in the creation of localized corrosion cells.

- Utilisation of hydrogen by microorganisms via a cathodic reaction depolarises the cathode which increases the rate of metal loss at the anode

- Microbial degradation of protective coatings on metal surfaces

- Microbial degradation of corrosion-inhibiting chemicals added to protect metals in industrial water systems — corrosion or scaling inhibitors

- Microbial production of metabolites which are corrosive organic and inorganic acids are often end-products of the metabolism of microorganisms

- Metabolic by-products such as $\mathrm{H}_{2} \mathrm{~S}$ can precipitate metal ions, such as iron to form FeS, which is corrosive itself.

According to Lee et al. (1995), MIC may be considered as the net result of the following processes:

- Transport and accumulation of materials from the bulk liquid to the metal surface. These materials can be soluble (microbial nutrients and corrosive chemicals) or particulate (viable microorganisms or inorganic particles)

- Microbial and electrochemical transformation processes within the biofilm and the metal surface. Microorganisms excrete extra-cellular polymers, which contribute to the biofilm deposit and promote adherence of corrosion products. Microbial transformation processes influence the corrosivity of the microenvironment at the biofilm-metal interface. Abiotic processes influence the rate, extent, and distribution of colonizing microbial species, as well as the chemical composition and physical properties of the resulting biofilm.

- Erosion and detachment from the surface of the film. These processes limit the overall extent of fouling deposit accumulation.

There are five factors, which are believed to contribute to MIC:

- The formation of oxygen concentration cells

- Formation of ion concentration cells

- Activities of iron- and manganese-oxidising bacteria

- Microbiological acid production

- Creation of anaerobic conditions promoting growth of SRB (Cloete \& Fleming 1997)

MIC can involve a plethora of organisms and mechanisms; effects may be specific as with $\mathrm{Fe}^{2+}$ to $\mathrm{Fe}^{3+}$ oxidation by Gallionella or the production of organic acids by Cladosporium, or of a more general character as with differential aeration cells arising from colonial growth or biofilm patchiness (Barton 1997). According to Cloete and Flemming (1997), electrochemical processes can be initiated or augmented by microbes. The simplest approach is therefore to consider the various metabolic activities concerned, and examine how each can affect metal surfaces. These metabolic activities are:

- Absorption of nutrients (including oxygen) by microbial growths adhering to metal surfaces

- Liberation of corrosive metabolites or end-products of fermentative growth (i.e. organic acids)

- Production of sulphuric acid from reduced sulphur compounds by chemolithotrophic autotrophs of the genus Thiobacillus

- The interference with the cathodic process in oxygen-free conditions by SRB (Cloete \& Flemming 1997) 


\section{PROCESS ANALYSIS OF MIC}

Systems undergoing MIC can be categorized as follows:

- Gas

- Bulk liquid

- Fouling deposits

- Substratum (Lee et al. 1995; Figure 1).

The corrosion rate and probably also the corrosion mechanism depend upon the different types of biofilms, which develop (Lee et al. 1995). The water chemistry and fluid dynamics of the system under study, in turn, affect the developing of biofilms. There are three biofilm systems, which may be considered (see Figure 1)

- A totally aerobic biofilm, where oxygen is present in the bulk liquid and also penetrates through the entire biofilm

- A totally anaerobic biofilm, where oxygen is absent from both bulk liquid and biofilm

- An aerobic/anaerobic biofilm, where oxygen is present in the bulk liquid and where anaerobic microniches and/or an anaerobic layer exist in the biofilm (Lee et al. 1995)

Accordingly, biocorrosion will be discussed under these three biofilm systems.

\section{Aerobic Processes}

Oxygen acts as the electron acceptor at the cathodic sites, in aerobic corrosion processes, to form hydroxides (Ford \& Mitchell 1990). Limited information is available about the influence of microorganisms on mechanisms of aerobic corrosion because of the assumption that abiotic oxidative processes are much more rapid. The importance of microorganisms in aerobic degradation of metals may be significantly underrated (Ford \& Mitchell 1990).

According to Lee et al. (1995), a uniform coverage by an aerobic biofilm may substantially decrease the corrosion rate due to the oxygen consumption and increased mass transfer resistance since the corrosion rate of steel in aerobic bulk liquid is controlled by the transport of dissolved oxygen (DO). It was also reported that agar-coated steel (simulated slime) demonstrated very high polarization resistance and correspondingly low corrosion rates.

The formation of ion concentration cells, bacterial polymer-metal interactions, activities of metal-transforming and acidproducing bacteria, and thermophillic reactions are other aerobic microbial processes that may accelerate corrosion (Ford \& Mitchell 1990). According to Ford and Mitchell (1990), the most apparent influence of an aerobic community on a metal surface is the creation of differential aeration cells. This process is known as tuberculation (Lee et al. 1995). Oxygen reduction occurs around the tubercle base and at the inner magnetite shell, while anodic iron dissolution occurs underneath the tubercle (Figure 2) (Lee et al. 1995). Ferrous ions generated in the anodic region migrate through the overlaying material, producing an anion flux opposite to the outward ferrous ion migration (Lee et al. 1995). Due to the increased concentration of an-ions such as chloride, the $\mathrm{pH}$ eventually decreases within the tubercle.

Biofilms, which form under aerated conditions, cause corrosion by the formation of differential aeration cells or concentration cells. Thus aerobic corrosion occurs when the oxide film is damaged, or oxygen is kept from the metal surface by the microorganisms and rapid pitting or corrosion occurs under the biofilm (Borenstein 1994).

Due to the fact that microbial and chemical corrosion enhances each other in aerobic conditions, it is difficult to differentiate between the two processes (Ford \& Mitchell 1990).

\section{Microorganisms Involved in Aerobic Biocorrosion}

\section{Corrosion Caused by Sulphur Oxidisers}

Bacteria can release aggressive metabolites, such as organic (acetic, succinic, isobuteric, etc.) or inorganic acid (sulphuric) (Borenstein 1994). Corrosion occurs underneath these bacteria, 

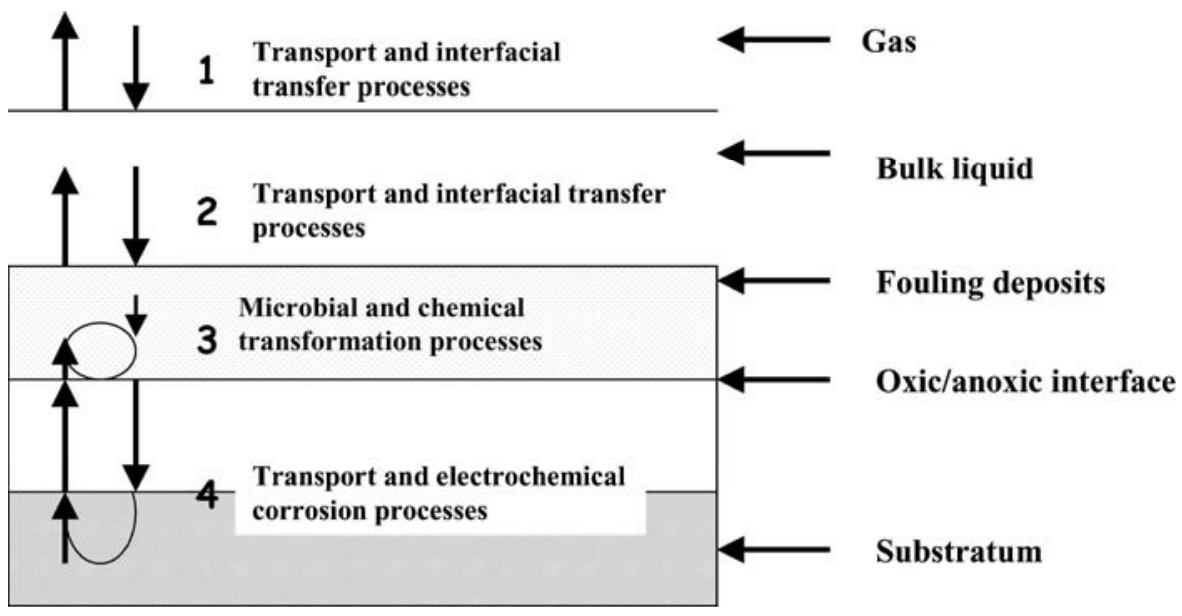

FIG. 1. The microbial corrosion system: interaction between various compartments (Lee et al. 1995).

Bulk liquid phase
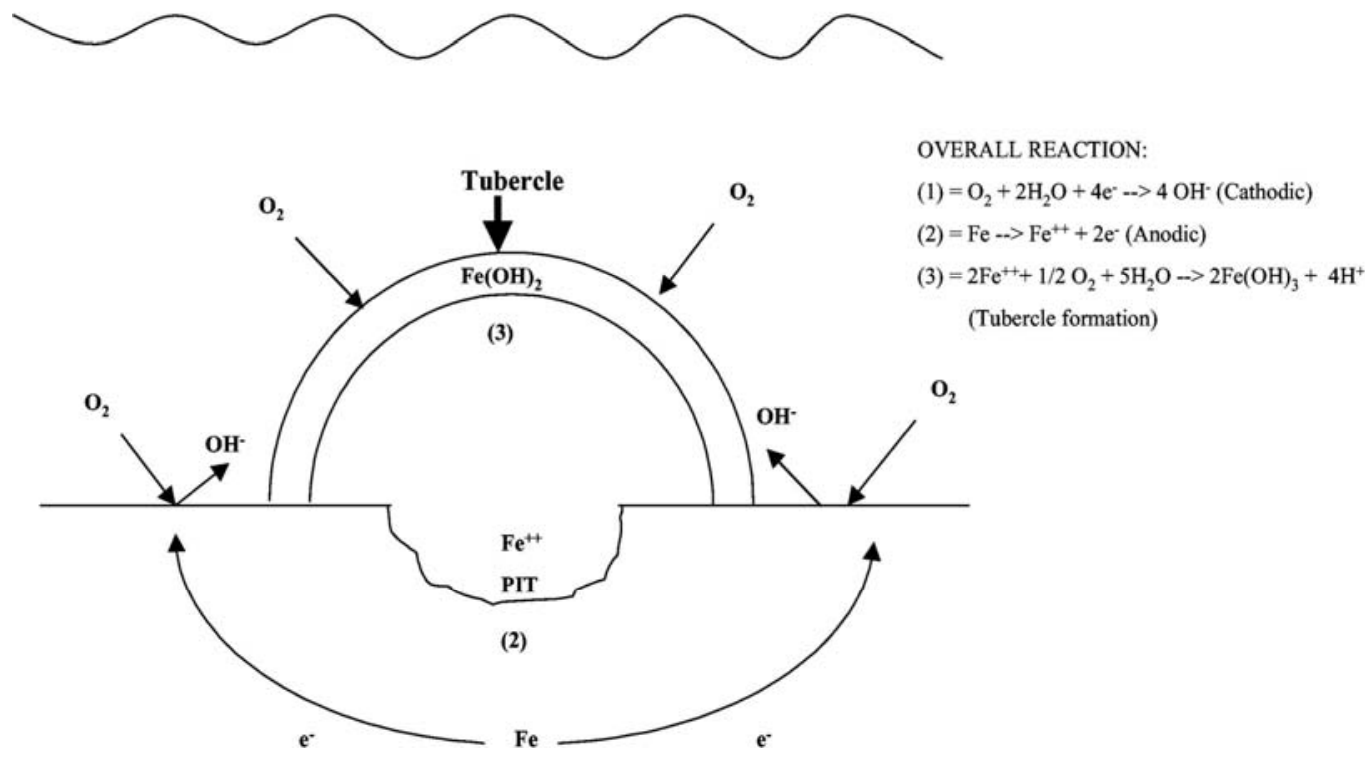

FIG. 2. Differential aerationcell formed by oxygen depletion under a microbial surface film (Ford \& Mitchell 1990).

with under-deposit corrosion caused by acid-producing bacteria, as shown in Figure 3 (Borenstein 1994).

The thiobacilli are a group of aerobic, chemolithotrophic autotrophs and obtain energy for $\mathrm{CO}_{2}$ fixation by a number of related reactions involving the oxidation of sulphur, hydrogen sulphide, or other reduced sulphur compounds to sulphuric acid (Prescott et al. 1990; Cloete \& Flemming 1997). In stressing the importance of anaerobic corrosion by SRB, corrosive effects of acids produced by microorganisms may be overlooked (Iverson 1987). Sulphur oxidisers chiefly of the genus Thiobacillus form sulphuric acid, which is a strongly corrosive agent, especially in concrete structures where the steel is corroded and the carbonates solubilized (Brözel \& Cloete 1989).

The following series of interlinked reactions performed by Thiobacillus species leads to the formation of free sulphuric acid (Cloete \& Flemming 1997):

$$
\begin{gathered}
2 \mathrm{H}_{2} \mathrm{~S}+2 \mathrm{O}_{2}=\mathrm{H}_{2} \mathrm{~S}_{2} \mathrm{O}_{3}+\mathrm{H}_{2} \mathrm{O} \\
5 \mathrm{Na}_{2} \mathrm{~S}_{2} \mathrm{O}_{3}+4 \mathrm{O}_{2}+\mathrm{H}_{2} \mathrm{O}=5 \mathrm{Na}_{2} \mathrm{SO}_{4}+\mathrm{H}_{2} \mathrm{SO}_{4}+4 \mathrm{~S} \\
4 \mathrm{~S}+6 \mathrm{O}_{2}+4 \mathrm{H}_{2} \mathrm{O}=4 \mathrm{H}_{2} \mathrm{SO}_{4}
\end{gathered}
$$


T. thiooxidans and T. concretivorus can grow at $\mathrm{pH} 0.7$, and the effects of sulphuric acid at these concentrations on metals and concrete are evident (Cloete \& Flemming 1997). T. ferrooxidans is of particular interest, as it is able to oxidise both ferrous iron and sulphur compounds (Borenstein 1994). T. ferrooxidans is used in the recovery of metals from low-grade sulphide ores, and produces sulphuric acid from the mineral pyrite $\left(\mathrm{FeS}_{2}\right)$ (Cloete \& Flemming 1997). Resulting acidic mine waters can cause serious corrosion of pumping machinery.

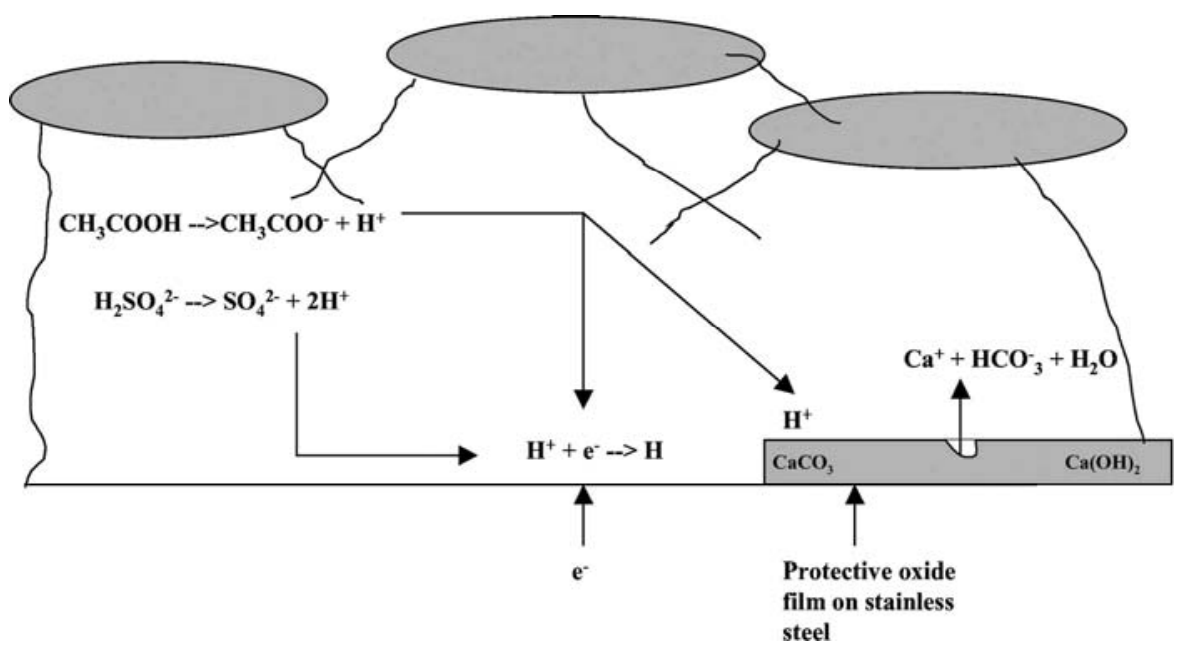

FIG. 3. Acid production (organic or inorganic) by adherent film-forming bacteria with consequent promotion of electron removal from cathode by hydrogen or dissolution of protective calcareous film on stainless steel surface (Borenstein 1994).

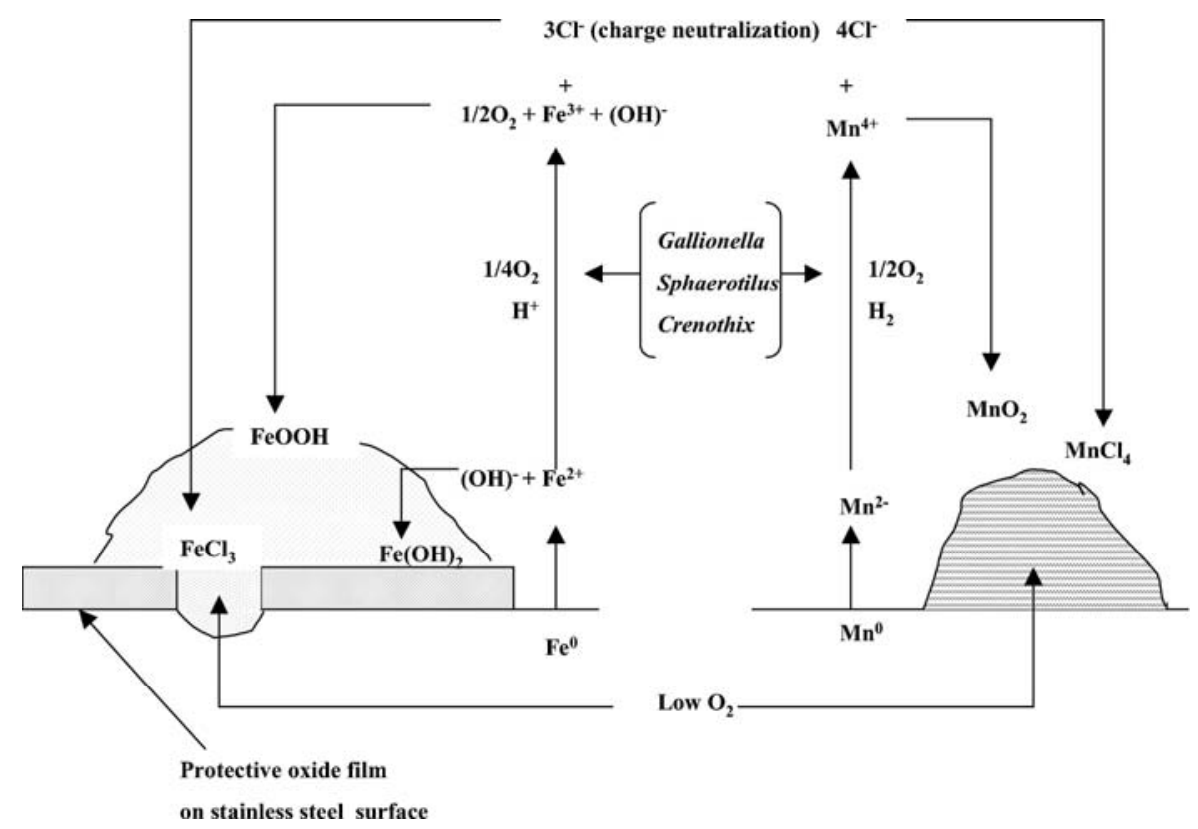

FIG. 4. Iron and manganese oxidation and precipitation in presence of filamentous bacteria. Stainless steel pitting in presence of chloride ions concentrated at surface in response to charge neutralization of ferric and manganese cations (Borenstein 1994).

According to Borenstein (1994) it was showed that under laboratory conditions aerobic acetic acid-producing bacteria could accelerate the corrosion of cathodically protected stainless steel in synthetic salt solution. The acetic acid destabilizes or dissolves the calcareous film that formed during cathodic polarization.

\section{Corrosion Caused by Iron or Manganese Bacteria}

Two types are included: the stalked bacteria in the genus Gallionella, and filamentous bacteria in the genera Sphaerotilus, Crenothrix, Leptothrix, Clonothrix, and Lieskeella (Iverson 1987). These aerobic iron bacteria oxidise ferrous to ferric iron 
$\left(\mathrm{Fe}^{2+}=\mathrm{Fe}^{3+}+\mathrm{e}^{\prime}\right)$, catalysing the deposition of tubercles, especially on stainless steel weld seams (Brözel \& Cloete 1989).

Gallionella exude metal oxide and produce insoluble waste high in iron and manganese (Borenstein 1994). They seem to concentrate chloride ions, which aggravates corrosion, particularly in crevice conditions and in austenitic stainless steels. Members of the filamentous bacterial genus Leptothrix deposit ferric oxides in their sheath (Cloete \& Flemming 1997).

The iron and manganese bacteria may be aerobic and can oxidize ferrous iron to ferric iron, which can attract the chloride ion and produce ferric iron, which can attract the chloride ion and produce ferric chloride (Figure 4) (Borenstein 1994). Ferric chloride is extremely aggressive and pits stainless steel and the deposits from the bacteria are rich in ferric chloride, and deposits aggressively attack austenitic stainless steel (Borenstein 1994). Pedomicrobium manganicum oxidises manganese in drinking water systems, and binds colloidal $\mathrm{MnO}_{2}$ in the extracellular polysaccharide, they can even oxidise ferrous iron on stainless steel (Brözel 1990). Metallogenium, Pedomicrobium, and Leptothrix species oxidize manganese $\left(\mathrm{Mn}^{2+}\right)$ and deposit $\mathrm{Mn}^{4+}$ salts outside the cell wall (Cloete \& Flemming 1997). The iron bacteria normally contribute to corrosion by excessive slime masses creating differential oxygen concentrations and thus concentration cells (Von Holy 1985).

\section{Corrosion Caused by Other Aerobic Bacteria}

In addition to the SRB, sulphur-oxidizing and iron bacteria, bacteria in the genus Pseudomonas and pseudomonas-like organisms have been reported in connection with cases of corrosion (Iverson 1987). Pseudomonas is an aerobic slime-former and often forms thin films combined corrosion deposits on metal surfaces (Borenstein 1994). Various Pseudomonas isolates have been implicated in reduction of ferric to ferrous iron, exposing steel to further oxidation as ferrous iron compounds are more soluble and the protective ferric iron layer is solubilized by this process (Cloete \& Flemming 1997). Pseudomonas species are most prevalent in industrial water environments along with several other slime-forming bacteria, where their primary role appears to be in colonising metal surfaces, thereby creating oxygen-free environments, which harbor SRB (Iverson 1987).

Slime-formers, as their name so subtly implies, form slime. Pseudomonas, Escherichia, Flavobacterium, Aerobacter, and Bacillus are included in this group. They grow in a patchy distribution over the metal surface and exclude oxygen via respiration; the slime impedes oxygen diffusion, creating an oxygen concentration cell. The slime plays a role in the aggregation of bacteria in flocks and in films on surfaces (Borenstein 1994).

\section{Anaerobic Processes}

Various authors have associated the SRB as the most widely distributed and economically important organisms with anaerobic corrosion, especially Desulfovibrio desulfuricans (Hamilton 1985; Ford \& Mitchell 1990; Boivin \& Costerton 1991; Crombie et al. 1980; Lee et al. 1995; Barton 1997). According to Barton (1997), SRB is the principal causative organism in MIC of platform structures, transmission lines, and general equipment, they are the likely cause of major reservoir damage including souring of the produced oil and gas, and plugging of the geological formation (Barton 1997). Other microorganisms involved in anaerobic biocorrosion are MPB, iron-reducing bacteria and hydrogen-producing bacteria (Boopathy \& Daniels 1991; Little et al. 1997; Ford \& Mitchell 1990; Bro“zel 1990).

\section{Proposed Mechanisms for Anaerobic Corrosion}

Two questions have always been asked in attempts to understand the corrosion mechanisms. The first question is what the nature of the cathodic reaction is which prevents the electrolytic cell from becoming polarized due to the build-up of a hydrogen overpotential and the second, what, if any, is the role of sulphide in the overall corrosion process (Hamilton 1985)?

Von Wolzogen Kuhr and van der Vlugt (1934) first postulated the most widely accepted theory for the mechanism of corrosion of iron and steel by cathodic depolarization. The essential step in this theory involves the removal of hydrogen (cathodic depolarisation) by the hydrogenase system of the SRB (Iverson 1987). The cathodic depolarisation theory is summarized in the following equations (De Bruyn 1992).

Initial reaction of iron placed in an aqueous environment:

$$
\begin{aligned}
2 \mathrm{H}_{2} \mathrm{O} & \rightarrow 2 \mathrm{H}^{+}+2 \mathrm{OH}^{-} \\
\mathrm{Fe} & \rightarrow \mathrm{Fe}^{2+}+2 \mathrm{e}^{-} \quad \text { (anode) } \\
2 \mathrm{H}^{+}+2 \mathrm{e} & \rightarrow 2 \mathrm{H} \quad \text { (cathode) }
\end{aligned}
$$

A protective film of hydrogen is formed on the metal surface. Bacterial interaction:

$$
\begin{aligned}
\mathrm{SO}_{4}{ }^{2-}+8 \mathrm{H}^{+} & \rightarrow \mathrm{S}^{2-}+4 \mathrm{H}_{2} \mathrm{O} \quad(\text { cathodic depolarization) } \\
\mathrm{Fe}^{2+}+\mathrm{S}^{2-} & \rightarrow \mathrm{FeS} \quad \text { (anode) } \\
\mathrm{Fe}^{2+}+2 \mathrm{OH}^{-} & \rightarrow \mathrm{Fe}(\mathrm{OH})_{2} \quad \text { (cathode) }
\end{aligned}
$$


The overall result can be presented by:

$$
4 \mathrm{Fe}+\mathrm{SO}_{4}+4 \mathrm{H}_{2} \mathrm{O} \rightarrow \mathrm{FeS}+3 \mathrm{Fe}(\mathrm{OH})_{2}+2 \mathrm{OH}^{-}
$$

This scheme is certainly an oversimplification (Odom 1990). Other corrosive forces may be at work. For example, iron sulphide itself can chemically depolarise metal, and hydrogen sulphide or its oxidation products are chemically corrosive to iron and steel. Additionally, SRB may deposit corrosive phosphorus-containing metabolites or establish oxygen concentration cells on the metal surface (Odom 1990).

The literature on MIC has been filed with evidence for and against the depolarization hypothesis of Von Wolzogen Kühr, and Van der Vlught (1934) (Iverson 1987).

\section{The Role of Hydrogenase in Anaerobic Biocorrosion}

An important metabolic feature of many anaerobic microorganisms is the hydrogenase system responsible for the oxidation and production of molecular hydrogen. The hydrogenase system can be viewed as a major element responsible for the diversity of products in potentially useful anaerobic fermentations and as an essential activity for the cycling of inorganic compounds in nature (Fauque et al. 1988). Von Wolzogen Kühr and van der Vlugt (1934) postulated that the SRB stimulated the corrosion reaction by removing atomic or cathodic hydrogen, thereby depolarizing the cathode (Hardy 1983). However, much of the experimental evidence offered in support of the depolarization theory has been questioned, on the grounds that the electrochemical cathodic depolarizations observed could not be attributed solely to the action of bacterial hydrogenase (Hardy 1983).

Hydrogen is an interspecies electron and proton transfer metabolite in microbial foods chains, and its metabolism in these organisms helps to explain corrosion of metals (Odom 1990). The following mechanism for the hydrogen electrode reaction in the absence of $\mathrm{H}_{2} \mathrm{~S}$ is generally accepted (Lee et al. 1995). A primary step (Equation 8) coupled with the molecular recombination desorption step (Equation 9) or with the electrochemical desorption step (Equation 10):

$$
\begin{aligned}
& \mathrm{M}+\mathrm{H}^{+}=\mathrm{M}-\mathrm{H}_{\mathrm{ads}} \\
& \mathrm{M}-\mathrm{H}_{\mathrm{ads}}+\mathrm{M}-\mathrm{H}_{\mathrm{ads}}=\mathrm{H}_{2}+2 \mathrm{M} \\
& \mathrm{M}-\mathrm{H}_{\mathrm{ads}}+\mathrm{H}^{+}+\mathrm{e}^{-}=\mathrm{H}_{2}+\mathrm{M}
\end{aligned}
$$

When $\mathrm{H}_{2} \mathrm{~S}$ is present, there is an increase in proton discharge but the hydrogen evolution rate is suppressed (Lee et al. 1995). The accumulation of SRB on steel surfaces minimises the diffusional distance between the cathodic hydrogen and the bacteria within the biofilm system. The hydrogen evolution rate is suppressed in the presence of $\mathrm{H}_{2} \mathrm{~S}$ and it is doubtful that the uptake of $\mathrm{H}_{2}$, as related to the hydrogenase activity, is the rate-controlling step for SRB-enhanced corrosion (Lee et al. 1995).

The activity of the hydrogenase enzyme may be either directly involved in depolarising cathodic hydrogen from the metal surface or indirectly involved in the production of the metabolic end products cited and therefore plays and important role in anaerobic biocorrosion (Figure 5) (Bryant \& Laishley 1989).

\section{Corrosion by Hydrogen-Consuming Bacteria}

Sulphate reducing bacteria. Until recently, anaerobic MIC was thought to be mediated by only two genera of hydrogenaseproducing SRB, Desulfovibrio and Clostridium (Ford \& Mitchell 1990). However, a number of other hydrogenase-producing, hydrogen-utilizing sulphate reducers have recently been isolated (Ford \& Mitchell 1990). A number of authors have shown that the presence and activity of hydrogenase may be regarded as a good indicator of biocorrosion activity (Pankhania et al. 1986). Accelerated corrosion rates have been observed when iron, corroded by SRB, is exposed to intermittent aerobic-anaerobic

conditions (Ford \& Mitchell 1990). A similar effect of aeration on mild steel was observed and it was proposed that the biogenic sulphide film differentiated into anodic and cathodic sites as a result of the aeration (Table 1). It was suggested that sulphideoxidizing bacteria are present within the anaerobic microbial community and that aeration may cause these bacteria to become active, producing acidic metabolites that considerably enhance the corrosion reactions (Ford \& Mitchell 1990). 


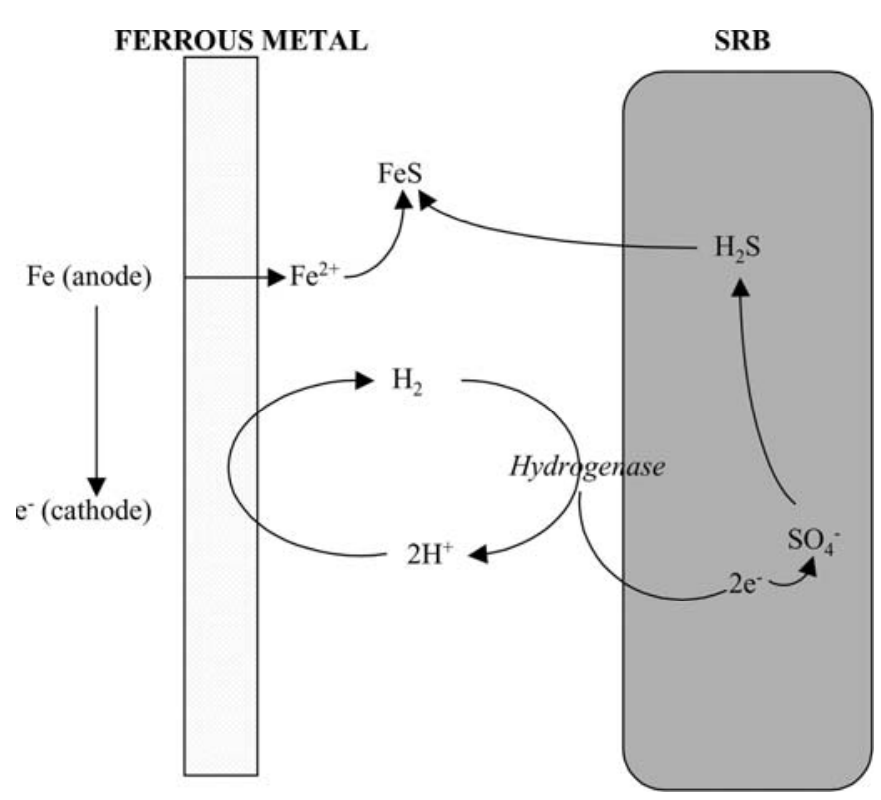

FIG. 5. The proposed function of hydrogenase in anaerobic biocorrosion (Bryant \& Laishley 1989).

TABLE 1

Some typical hydrogen-utilising sulphur bacteria (Ford \& Mitchell 1990)

\begin{tabular}{lll}
\hline Species & Carbon source & Electron acceptor \\
\hline $\begin{array}{c}\text { Desulfovibrio } \\
\text { sapovorans } \\
\begin{array}{c}\text { Desulfobulbus } \\
\text { propionicus }\end{array}\end{array}$ & Atty acids & Sulphate \\
$\begin{array}{c}\text { Desulfotomaculum } \\
\text { acetoxidans }\end{array}$ & Propionate & Sulphate, nitrate \\
$\begin{array}{c}\text { Desulfuromonas } \\
\text { Acetoxidans }\end{array}$ & Acetate & Sulphate \\
$\begin{array}{c}\text { Desulfobacter } \\
\text { postgatei } \\
\begin{array}{c}\text { Desulfosarcina } \\
\text { viriabilis }\end{array}\end{array}$ & Acetate & Elemental sulphur \\
$\begin{array}{c}\text { Desulfonema } \\
\text { magnum }\end{array}$ & Acetate & Sulphate \\
\hline
\end{tabular}

It was suggested that the transient hydrogen utilization might have resulted from the poisoning of atomic hydrogen to molecular hydrogen by traces of sulphide, molecular hydrogen being the substrate for the hydrogenase system rather than atomic hydrogen (Hardy 1983). Any build-up of atomic hydrogen resulting from this sulphide poisoning could cause hydrogen uptake into the

steel itself, resulting in hydrogen embrittlement and stress corrosion cracking.

\section{The Role of SRB in Anaerobic Corrosion}

SRB have been recognized as the most significant contributors to MIC. They have been branded as the most troublesome microorganisms to control because of their anaerobic growth potential underneath biological slimes or biofilms (Von Holy 1987). According to Von Holy (1987), MIC mediated by SRB is intimately linked to the presence of complex stratified biofilms, which are held together by massive excretions of microbial extracellular polymeric substances (EPS or glycocalyx). In the presence of $\mathrm{SRB}$, steel and other iron alloys in an anoxygenic aqueous surrounding corrode up to four times as fast than with normal oxygen 
promoted corrosion (Brözel \& Cloete 1989).

SRB are usually not the first group of organisms to become established in fresh water systems (Cloete \& Flemming 1997). Initially, microbial populations are composed predominantly of aerobic microorganisms. As these grow, biofilms accumulate and a strong reducing environment develops at the point of attachment. The SRB now begin to grow. The metabolites of the aerobic microorganisms not only produce reducing conditions but also provide nutrients for the SRB, which permit them to grow at a rapid rate. Corrosion develops in the areas where the SRB have grown to high numbers. Thus anaerobic MIC can occur in fresh water systems. While the recirculating water in these systems contains free oxygen, the areas in which the SRB grow are anaerobic (Cloete \& Flemming 1997).

Lee and Characklis (1993) studied corrosion of mild steel under anaerobic biofilm. A mixed population biofilm, including SRB in a continuous flow system were used. No correlation was observed between corrosion and SRB in the absence of ferrous iron. Furthermore, corrosion of mild steel in the SRB environment was determined by the nature of the metal and environmental conditions such as dissolved iron concentration. The experimental investigations, which they reported, provided strong evidence that corrosion of mild steel was insignificant even in the presence of an active SRB biofilm. This might be attributed to the high activation energy for hydrogen reduction and/or recombination. However, in the combined presence of an SRB biofilm with dissolved oxygen, dissolved iron, and iron sulphide, corrosion is enhanced.

Four main predisposing factors to microbiological corrosion by SRB have been identified:

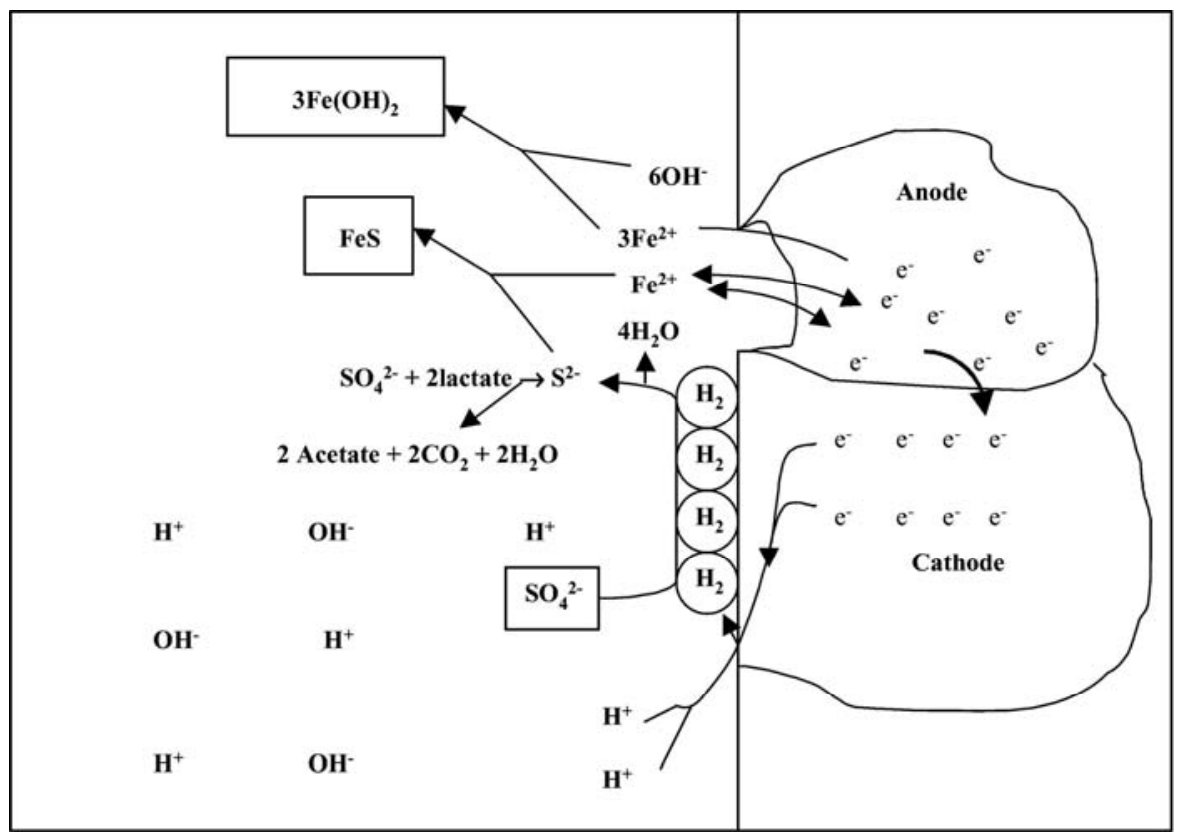

FIG. 6. Proposed mechanism of anaerobic corrosion of iron in the presence of sulphate-reducing bacteria (Ford \& Mitchell 1990).

- high levels of available sulphate

- anaerobic conditions

- $\quad$ areas of low or no flow

- the presence of biological slime or other deposits (Von Holy 1987).

Characteristics of MIC by SRB:

- It occurs in anaerobic environments in the presence of water. Encrustations or "tubercles" on the metal harbour SRB and provide suitable anaerobic conditions for corrosion

- The corroded metal is pitted rather than evenly corroded. The rate of pitting increases with time, indicating that the process is of an autocatalytic character. Corroded pipes therefore perforate rather than disintegrate

- Cast iron leaves a carbon residue at the site of corrosion, and the metal becomes "graphitized" (Cloete \& Flemming 1997).

When exposed to pure cultures of SRB under strictly anaerobic conditions in the laboratory, a dramatic and distinctive type of corrosion occurs (Odom 1990). For example, stainless steel develops a characteristic deep pitting after several weeks of exposure 
to Desulfovibrio desulfuricans, whereas carbon steel develops a more generalised surface corrosion, and severe endgrain corrosion of the metal is the primary symptom. The danger in such highly localized corrosion is that it develops rapidly and often is difficult to detect before metal failure has already occurred.

According to Lee et al. (1995), mass transfer resistance into the biofilm limits the activity of SRB in an anaerobic biofilm and/or diffusional resistance within the biofilm and activity is normally expressed as the sulphate reduction rate or sulphide production rate. Accelerating corrosion of steel by SRB activities can be attributed either directly to removal of hydrogen or indirectly to the production of $\mathrm{H}_{2} \mathrm{~S}$. Only an indirect correlation between biofilm SRB activity and corrosion rate was found (Lee et al. 1995). The mechanism of corrosion appeared to depend on the chemical and physical nature of the corrosion products rather on the SRB activity. A similar lack of correlation between biofilm SRB activity and corrosion rate in an iron-free medium was found (Lee \& Characklis 1993). In this instance, the biofilm SRB activity was controlled by the substrate-loading rate, which equalled the product of the dilution rate and consumed substrate concentration divided by the surface area (Lee et al. 1995). There was no detectable difference in either weight loss or electrochemical measurements as SRB activity was increased.

According to Barton (1997) it is now possible to identify with some degree of certainty many aspects of the mechanism of SRB-induced biocorrosion (Figure 6):

- $\quad$ SRB-induced biocorrosion is an electrochemical event

- The crucial property is the production of sulphide, which reacts with the released metal ions to produce a range of iron sulphides. The chemical and physical nature of these sulphides is critically influenced by environmental parameters.

- The relative concentrations of free sulphide anion and soluble iron will determine both the chemical nature and physical form of the sulphide corrosion products.

- Exposure to oxygen both markedly accelerates corrosion and leads to the conversion of the primary sulphide products to pyrite and elemental sulphur

- Naturally occurring SRB-induced biocorrosion is invariably characterised by localized metal dissolution and the formation of pits. This is not always the case in various laboratory simulations of corrosive processes.

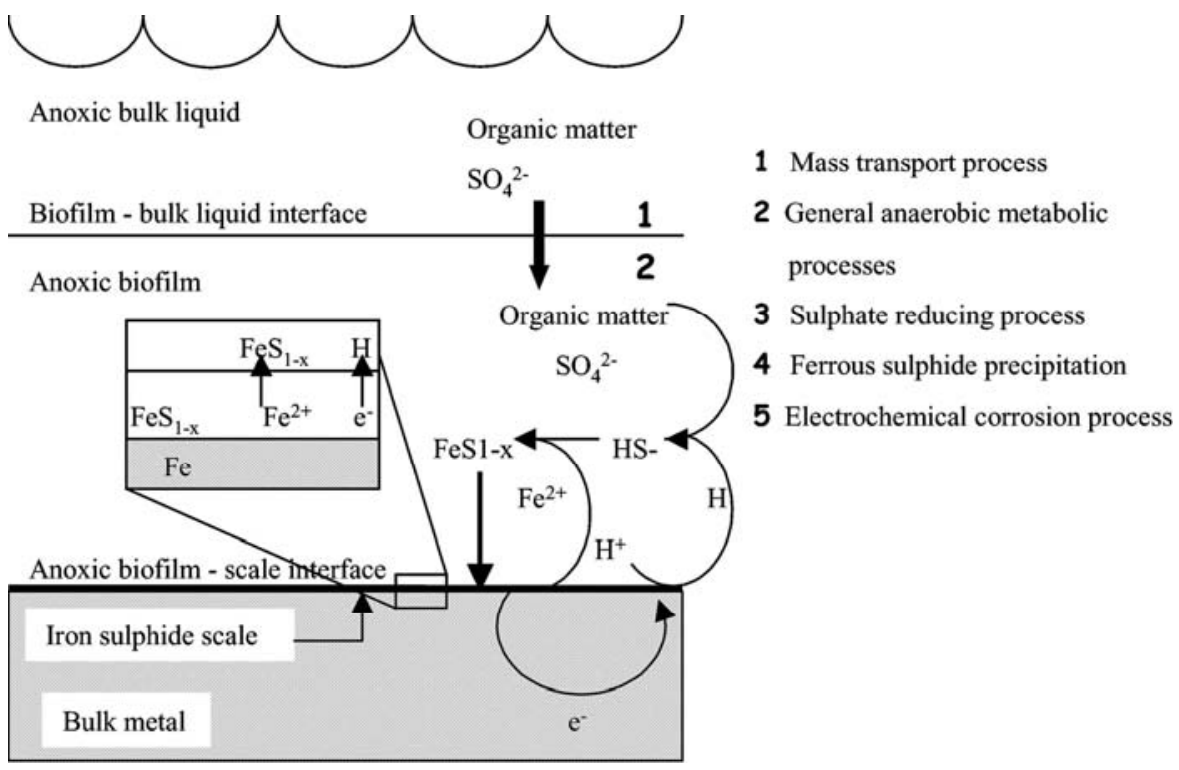

FIG. 7. Schematic diagram of transport and transformation processes contributing to corrosion of mild steel in a totally anaerobic biofilm (Lee et al. 1995).

Figure 7 summarizes the processes contributing to corrosion of mild steel in a totally anaerobic biofilm and are as follows: (1) transport of nutrients to the biofilm, (2) general anaerobic metabolic processes, (3) sulphate reducing process, (4) ferrous sulphide precipitation, and (5) electrochemical corrosion process (Lee et al. 1995).

According to Lee et al. (1995) the corrosion rate of mild steel is not controlled directly by SRB activity, but indirectly through the nature of reduced iron sulphides formed as corrosion products.

Thus, SRB can stimulate the cathodic reaction by:

- The removal of hydrogen (directly)

- Formation of iron sulphides (indirectly)

- Dissolved oxygen (Lee et al. 1995) 
According to Hardy (1983), the following findings concerning the physiology of SRB, particularly relating to the role of hydrogenase, are of possible significance in the context of the depolarization theory:

- Hydrogen metabolism in SRB has been shown to be much more significant in the natural environment than was previously recognized. This has been substantiated by the finding that growth on hydrogen supplied as the sole energy source is a widespread ability among the SRB. Oxidation of cathodic hydrogen might, therefore, be a significant source of energy for sulphate reduction.

- Two, possibly different, hydrogenases have been found in Desulfovibrio spp: one is a periplasmic enzyme (associated with the outer membranes) and the other, an intracellular cytoplasmic enzyme. The periplasmic enzyme appears to be the uptake enzyme when cells are grown on hydrogen. There is some evidence to suggest that the periplasmic enzyme constitutes a greater proportion of the total hydrogenase present in hydrogen-grown cells than of the hydrogenase in lactate-grown cells. It is feasible, therefore, that the type of energy source available during the growth of cells, which are then used in depolarisation experiments, might influence the cells' ability to use cathodic hydrogen.

According to Speece (1996), sulphate reduction is strongly enhanced by the addition of $\mathrm{H}_{2}$ gas or hydrogen precursors such as ethanol. It was established that formate did not stimulate the activity of SRB, but the SRB, even for their preferred substrate $\mathrm{H}_{2}$ apparently endured stiff competition from the hydrogenotrophic MPB. On average only $50 \%$ of the available $\mathrm{H}_{2}$ was captured by the SRB.

Studies in support of the depolarisation theory employed hydrogenase-positive Desulfovibrio spp. with benzyl viologen as terminal oxidant, thus obviating any potential complication from the production of sulphide (Hamilton 1985).

In another experiment, polarization and potentiostatic techniques were used to demonstrate the cathodic polarisation of metal test coupons caused by a washed cell suspension in an organic buffer (Booth \& Tiller 1960). According to Hamilton (1985), these techniques, in which the extra current required to maintain a controlled potential at the cathode is recorded, give a direct measurement of the corrosion rate. The hydrogenase-negative Desulfotomaculum orientis was completely inactive in this system (Hamilton 1985).

It was found that hydrogen was an important electron donor for SRB present in Salt Marsh Sediments during studies done by Nedwell and Banat (1981). During anaerobic studies conducted by Cord-Ruwisch and Widdel (1986), hydrogenase-positive Desulfovibrio strains, growing with limiting lactate concentrations in the presence of steel wool, formed more sulphide than observed with lactate alone. The additional sulphide originated from sulphate reduction with cathodically formed hydrogen from the steel surface. The hydrogenase negative $D$. sapovorans did not produce additional sulphide.

Pankhania et al. (1986) showed that Desulfovibrio vulgaris are able to grow on acetate plus $\mathrm{CO}_{2}$ as carbon source with $\mathrm{H}_{2}$ as the sole source of energy. The utilization of cathodic hydrogen from a mild steel electrode was demonstrated electrochemically and physiologically by $D$. vulgaris. $D$. vulgaris depolarised the metal electrode and growth on acetate under $\mathrm{N}_{2} / \mathrm{CO}_{2}$ was dependent on the presence of the electrode. Although the highest corrosion rate was observed under aerobic conditions, D. vulgaris significantly increased the corrosion rate under anaerobic conditions.

When carbon steel was exposed to three organisms (Eubacterium limosum, Desulfovibrio, sp. and Desulfobacter sp.), provided with $\mathrm{H}_{2} / \mathrm{CO}_{2}$, buthanol, glucose and acetate as carbon and electron source, a consortium of these bacteria utilising hydrogen gave rise to relatively high corrosion rates, with respect to corrosion resulting from bacteria supplied with organic electron sources (Dowling et al. 1992).

Brandis and Thauer (1981), showed that Desulfovibrio vul-garis, D. desulfuricans, and D. gigas could grow on $\mathrm{H}_{2}$ and sulphate as sole energy source. Thus, lithotrophic growth on $\mathrm{H}_{2}$ and sulphate is not a unique property of a few newly isolated Desulfovibrio strains as previously reported.

Using $\left[{ }^{35} \mathrm{~S}\right]$ sulphate to follow respiration, a resting cell suspension of SRB in buffered $0.5 \mathrm{M} \mathrm{NaCl}$ was found to be capable of removing and using hydrogen generated at cathodic sites on mild steel, low-carbon pipeline steel or platinum working electrodes (Hardy 1983). However, the relative amounts of the observed depolarization attributable to bacterial hydrogenase and that due to the sulphides produced could not be determined. It is unlikely that utilization of cathodically generated hydrogen coupled with sulphide production will be the dominant mechanism by which SRB cause corrosion of steel because of the relatively small

amounts of cathodic hydrogen. It must undoubtedly, a contributory factor.

Bryant et al. (1991) studied the effect of hydrogenase and mixed SRB populations on the corrosion of steel. Using mixed populations of SRB isolated from corroded and non-corroded oil pipelines assessed the importance of hydrogenase activity to corrosion of steel. It was found that biofilms, which developed on the steel studs, contained detectable numbers of SRB. However, the biofilm with active hydrogenase activity was associated with a significantly higher corrosion rate relative to noncorrosive biofilm with SRB but no measurable hydrogenase activity. Thus, hydrogenase activity present in the SRB may influence the biocorrosion process and also be subject to repression or induction mechanisms.

Brözel (1990) reported that many SRB could utilize hydrogen as energy source, or at least catalyse oxidation of hydrogen and that certain SRB can grow on hydrogen and sulphate as sole energy source. Although there was much controversy about utilization of cathodic hydrogen in older literature, it now appears to be an accepted fact (Brözel \& Cloete 1989). In this mechanism, where 
the combination of adsorbed $\mathrm{H}$ atoms to produce $\mathrm{H}_{2}$ gas is considered to be the rate-controlling step, bacteria effectively increase the hydrogen evolution rate and increase the corrosion rate accordingly (Lee et al. 1995).

\section{The Effect of Methanogenic Bacteria on Anaerobic Corrosion}

In many environments, MPB are found near SRB and may play a role in biocorrosion there, as well as in environments relatively free of SRB (Boopathy \& Daniels 1991). Boopathy and Daniels (1991) demonstrated that cathodic depolarisation was a mechanism responsible for corrosion and oxidation of elemental iron and mild steel; methane is produced as the result of the chemical production of low levels of $\mathrm{H}_{2}$ gas. Virtually all MPB use $\mathrm{H}_{2}$ as an electron donor, with $\mathrm{CO}_{2}$ as the sole source of carbon, although some can use other substrates as well (e.g., methanol or acetate; Figure 8) (Boopathy \& Daniels 1991).

\section{The Role of Iron-Reducing Bacteria in MIC}

A group of organisms about which much less is known in terms of role(s) in corrosion are the dissimilatory metal reducers (Little et al. 1997). Dissimilatory iron and/or manganese reduction occurs in several microorganisms, including anaerobic and facultative aerobic bacteria. Anodic depolarization by iron-reducing bacteria has been the subject of extensive investigation (Ford \& Mitchell 1990). Facultative anaerobes that were capable of using ferric ions, as terminal electron acceptors were isolated from oil production systems. These isolates were initially characterised as Pseudomonas sp. But have since been reclassified as Alteromonas putrefaciens strains (Ford \& Mitchell 1990). Their mode of action was to attach to mild steel, removing the passive $\mathrm{Fe}_{2} \mathrm{O}_{3}$ film and forming a dense fibrous mat. The surface of the metal was pitted beneath the mat as a result of anodic depolarization (Ford \& Mitchell 1990). The suggested mechanism is through reduction of the ferric ion, in this case an insoluble protective layer, to the soluble ferrous ion (Ford \& Mitchell 1990). It was later suggested that the combination of anodic and cathodic depolarisation, the latter by SRB, account for the severe corrosion of these pipe lines (Ford \& Mitchell 1990).

Little et al. (1997) used synthetic iron oxides as model compounds to simulate the mineralogy of passivating films on carbon steel. When carbon steel electrodes were exposed to Shewanella putrefaciens MIC was demonstrated electrochemically and microscopically. Metal-depositing bacteria produce visible tubercles that are unmistakable in their appearance (Little et al. 1997). Shewanella putrefaciens can use hydrogen as an electron donor for reduction of metals appearance (Little et al. 1997).

A

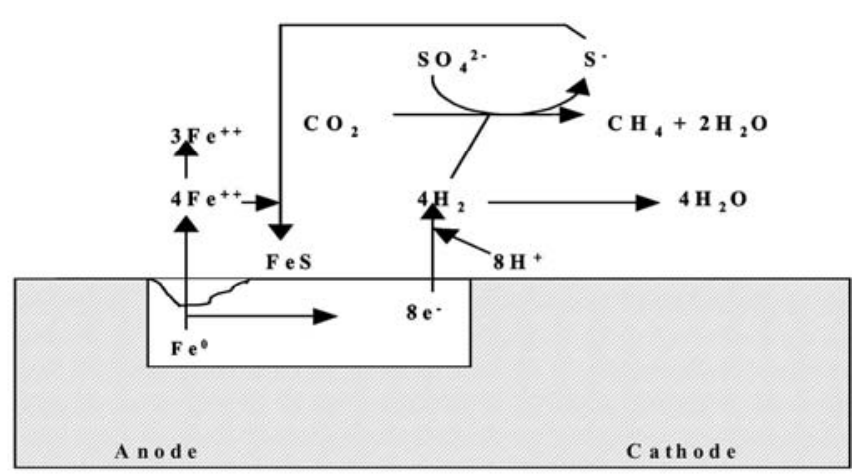

B

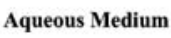

Ferrous Metal

Anode Cathode

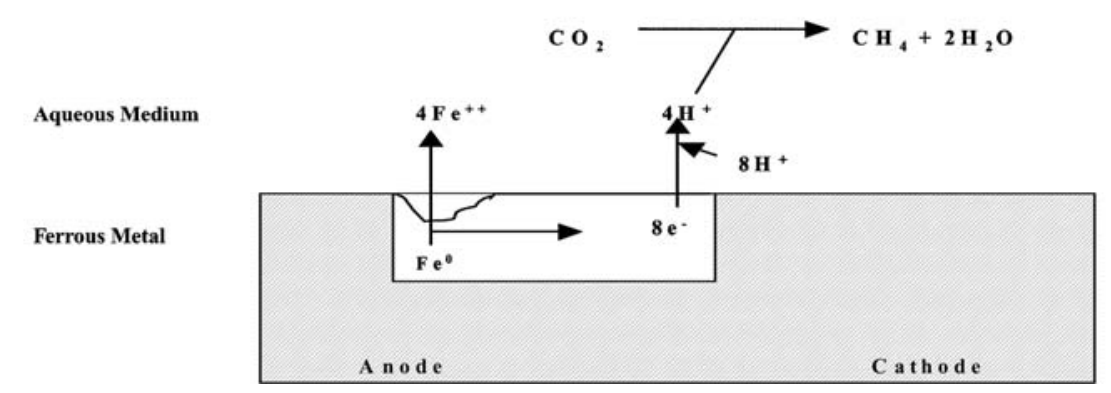

FIG. 8. The mechanism of cathodic depolarization in elemental iron as accelerated by sulphate-reducing bacteria (A) or by methanogenic bacteria (B) (Boopathy \& Daniels 1991).

As ferric iron is insoluble except at very low $\mathrm{pH}$, ferric salts protect the metal surface from further corrosion due to chemical activity (Brözel 1990). Ferrous salts are mostly soluble and therefore reduction of ferric salts results in removal of the protective 
layer. Therefore iron-reducing pseudomonas promotes corrosion indirectly (Brözel 1990).

\section{The Role of Other Hydrogenase-Positive Organisms in Anaerobic Biocorrosion}

Although many of the SRB have the ability to utilise hydrogen, there are also many other non-SRB that possess the enzyme hydrogenase and have the ability to produce sulphide from partially reduced inorganic sulphur compounds (Bryant \& Laishley 1989).

Various hydrogenase-positive Chlorophyta and Cyanophyta species utilize cathodic hydrogen (Brözel 1990). According to Iverson (1987), cathodic polarization studies on three strains of hydrogenase-positive Cyanophyta indicated that the organisms were able to utilise cathodic hydrogen. It has, however, been found that under healthy microalgal mats composed of Oscillatoria, colonial diatoms, and Enteromopha sp., the $\mathrm{pH}$ is raised to high values, which tends to reduce the corrosion rate. In areas where there is decay of the mat, the $\mathrm{pH}$ was lowered, probably due to the production of corrosive organic acids, causing differential pH corrosion cells as well (Iverson 1987). Conditions were also found rendered favorable for the growth of SRB.

A variety of hydrogenase-positive, photosynthetic, and non-photosynthetic bacteria have been tested in the laboratory for their corrosive effect by the cathodic polarization technique (Iverson 1987). Only small effects were noted. During laboratory studies, several heterotrophic bacteria, which form $\mathrm{H} 2, \mathrm{CO} 2$, and acids, have been reported to play an important role during the corrosion of iron (Iverson 1987).

In 1989, Bryant and Laishley studied the role of hydrogenase in anaerobic biocorrosion. Since all hydrogenases appear to be active in the reversible activation of the hydrogen molecule, hydrogenase from Clostridium pasteurianum was used as a test enzyme for investigating the role of cell-free hydrogenase in anaerobic biocorrosion of mild steel. Evidence was presented which demonstrated the activity of the hydrogenase enzyme in catalysing removal of cathodically, produced hydrogen from mild steel in the presence of the appropriate electron acceptors. The results from these experiments imply that dead cells may also provide, by virtue of their biochemical makeup, all the necessary ingredients to catalyse corrosion of mild steel. Bryant and Laishley (1989) summarized the results obtained in the form of four models (Figure 9).

\section{Corrosion by Iron Sulphides}

Booth et al. (1968) proposed an alternative mechanism for cathodic depolarization. In addition to utilization of polarising hydrogen by the bacterial hydrogenase system, there is evidence of depolarization of the cathode by iron(II)sulphide. It was also

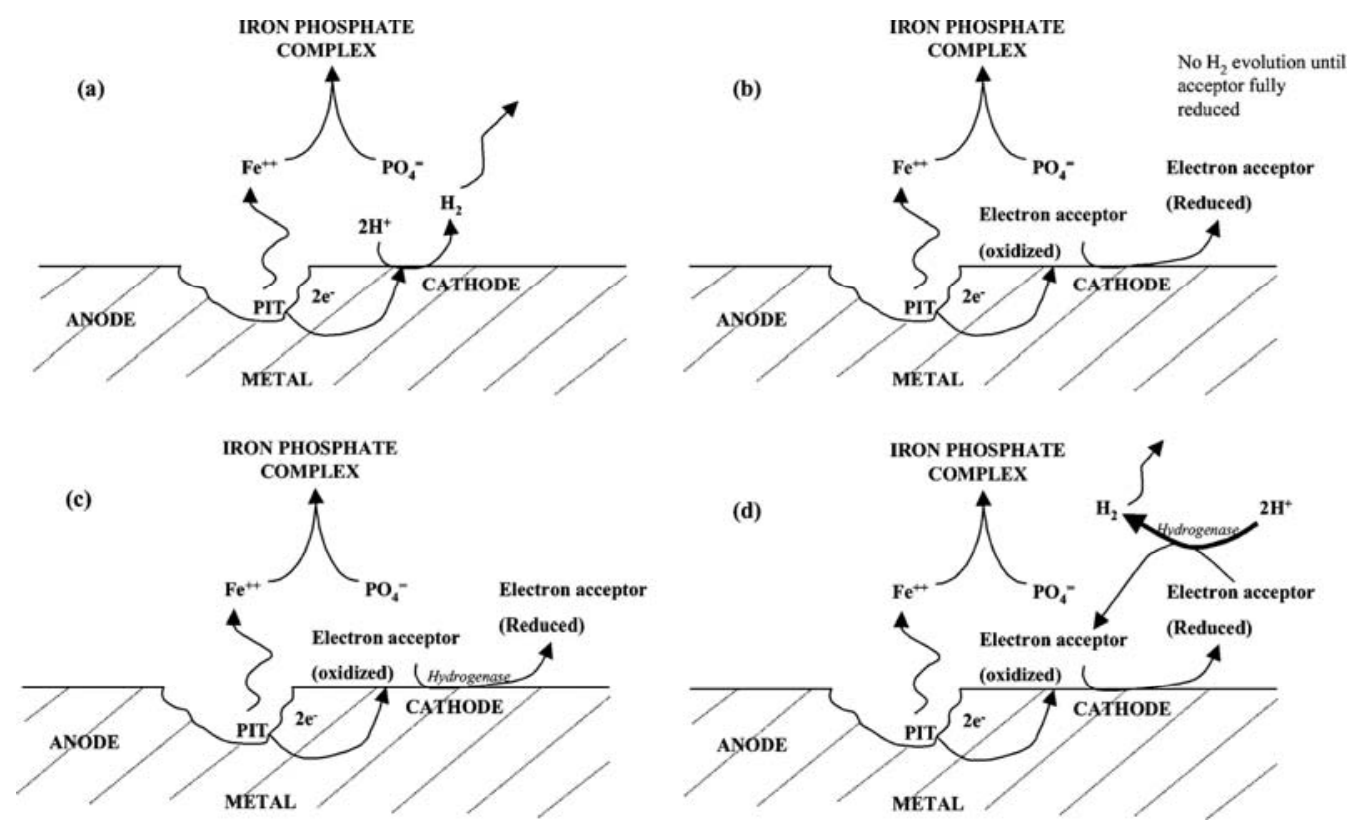

FIG. 9. Models integrating the effect of phosphate, evolution acceptors, and hydrogenase on hydrogen evolution from mild-steel surfaces. (a) The effect of phosphate on hydrogen evolution from the metal surface. (b) The effect of appropriate electron acceptors showing preferential reduction. No hydrogen evolution until acceptor fully reduced. (c) The catalytic effect of hydrogenase on cathodic reduction of the appropriate electron acceptor. (d) The reverse function of the hydrogenase when electron acceptor fully reduced prior to encounter with enzyme (Bryant \& Laishley 1989).

proposed that the cathodic reaction, that is, hydrogen evolution, occurred on the iron(II)sulphide formed by the reaction of the 
iron(II)ion with the bacterially produced sulphide ion (De Bruyn 1992).

SRB acts as cathodic depolarizers and produce corrosive hydrogen sulphide and thus, play a dual role in causing corrosion (Von Holy 1987). According to Von Holy (1987), cathodic depolarization is thought of as a biological catalyst, involving the enzyme hydrogenase present in the SRB cell. Bacterial action reduces the sulphate present in the water to sulphides, using the hydrogen to form hydrogen sulphide. The hydrogen sulphide reacts with the dissolved ferrous iron, which is released at the anode to form an iron sulphide precipitate (black) (Von Holy 1987).

The formation of iron sulphides in the presence of iron and Desulfovibrio desulfuricans, in a batch culture, was studied (Lee et al. 1995). The biogenic iron sulphides were identical with those produced by purely inorganic processes under the same conditions. It was therefore concluded that the biogenic and abiogenic iron sulphides could not be distinguished.

Several authors have investigated the effect of ferrous sulphide concentration in a suspended culture (Lee et al. 1995). Several findings were made:

- Based on a semi-continuous culture experiment, it was reported that the presence of sufficient concentration of ferrous ions in the medium to precipitate the biogenic sulphide and inhibit protective film formation, led to a great increase in corrosion rate

- In a semi-continuous culture the increase in ferrous ion concentration caused breakdown of the protective mackinawite film and the rate of corrosion after lime breakdown increase proportionally to the ferrous ion concentration Film breakdown in this instance was attributed to the transformation of mackinawite to nonprotective smythite and pyrrhotite, rather than to greigite (Lee et al. 1995).

Although SRB utilise cathodic hydrogen, the relatively low rates of sulphate respiration observed indicated that it was unlikely that cathodic hydrogen removal was the dominant mechanism whereby SRB induced corrosion (Hardy 1983). The concomitant generation of sulphide was probably or more significance in terms of corrosion (De Bruyn 1992). According to De Bruyn (1992) the consumption of cathodic hydrogen as well as the sulphide production of SRB may influence the anaerobic corrosion of iron.

An adherent sulphide film is formed in the presence of SRB when the system contains low concentrations of dissolved iron (Lee et al. 1995). It was shown that when the steel surface was pre-coated chemically with a layer of iron sulphide, followed by biofilm accumulation in an iron-free medium, some localised corrosion occurred (Lee et al. 1995). Aggregate of bacteria had iron sulphide crystal associated with inclusions were found inthe localized corrosion areas beneath the sulphide film and biofilm. Although biofilm accumulation reduced the spalling of the iron sulphide layer, as compared with abiotic conditions, the risk of localised corrosion is significant (Lee et al. 1995).

Results obtained by Lee and Characklis (1990) indicated that iron sulphide films on metal surfaces did not offer protection from anaerobic MIC. They concluded that:

- The anaerobic corrosion process at low hydrogen sulphide concentration at $\mathrm{pH} 8$ under continuous flow conditions was initiated at defect sites in the iron sulphide film or metal matrix and propagated through film spalling and rupture

- The loosely accumulated iron sulphide accelerated corrosion of mild steel due to cathodic-only depolarization, which is limited by concentration diffusion polarization

- Accumulation of biofilm on a precoated iron sulphide film could reduce spalling of iron sulphide film but could not avoid the risk of localized corrosion.

SRB stimulates the cathodic reaction indirectly by the formation of iron sulphides (Lee et al. 1995). Iron sulphides must have access to the bare steel surface for corrosion to occur by this mechanism (Lee et al. 1995). Once a galvanic cell is established, mild steel behaves as an anode and proton discharge and electron transfer occur on and through the irons sulphide (Lee et al. 1995). Iron sulphides increase the rates of corrosion by decreasing hydrogen over-voltage and/or adsorbing the cathodically produced hydrogen (Lee et al. 1995). A ferrous sulphide layer is formed on the metal surface by $\mathrm{Fe}^{2+}$ reacting with $\mathrm{H}_{2} \mathrm{~S}$ (produced by SRB at low free ferrous iron concentrations) (Brözel 1990). Interest was kindled in ferrous sulphide and its many colloidal and crystalline states prompted by the finding that bacterial hydrogenase activity alone could not explain metallic corrosion in the presence of SRB (Brözel \& Cloete 1989).

According to Brözel and Cloete (1989), this film initially protects the surface, decreasing the corrosion rate. However, the film is dependent on the free ferrous iron concentration. At low concentration $(25 \mu \mathrm{M})$ it transforms to the more corrosive greigite $\left(\mathrm{Fe}_{3} \mathrm{~S}_{4}\right)$ and crumbles at higher concentrations $(125 \mu \mathrm{M})$. These results provide pointless information for in situ corrosion where the metal surface is covered by a biofilm, which buffers ion motility and chelates ions. It was shown that where SRB had already established on the metal surface, subsequent reduction of free ferrous concentration had no effect on the corrosion rate, as SRB were in direct proximity to the metal surface (Brözel \& Cloete 1989).

According to Brözel and Cloete (1989), it was found conclusively that iron sulphide and not cathodic iron was the cathode, hydrogen evolution occurring there. It was found that especially a Pseudomonas isolate reduced ferric to ferrous iron, preventing film formation by increasing the free ferrous concentration (Brözel \& Cloete 1989). Apart from promoting corrosion in micro-aerophillic areas, this 
organism would clearly contribute to corrosion in older biofilms by activity distal to the corrosion rate (Figure 10).

\section{Sulphur and Sulphur Compounds}

Elemental sulphur has been observed around corrosion pits caused by the action of SRB. High corrosion rates of steel have been noted in the presence of elemental sulphur. Oxidation of sulphide to sulphur could occur abiotically or by the action of reduced sulphur oxidizing bacteria (De Bruyn 1992).

At or near neutral $\mathrm{pH}$ values, hydrogen sulphide produced by $\mathrm{SRB}$, mainly in the form of $\mathrm{HS}^{-}$ions, reacts with iron to form a partially protective film of iron sulphide that may afford varying degrees of corrosion protection (Iverson 1987). Under
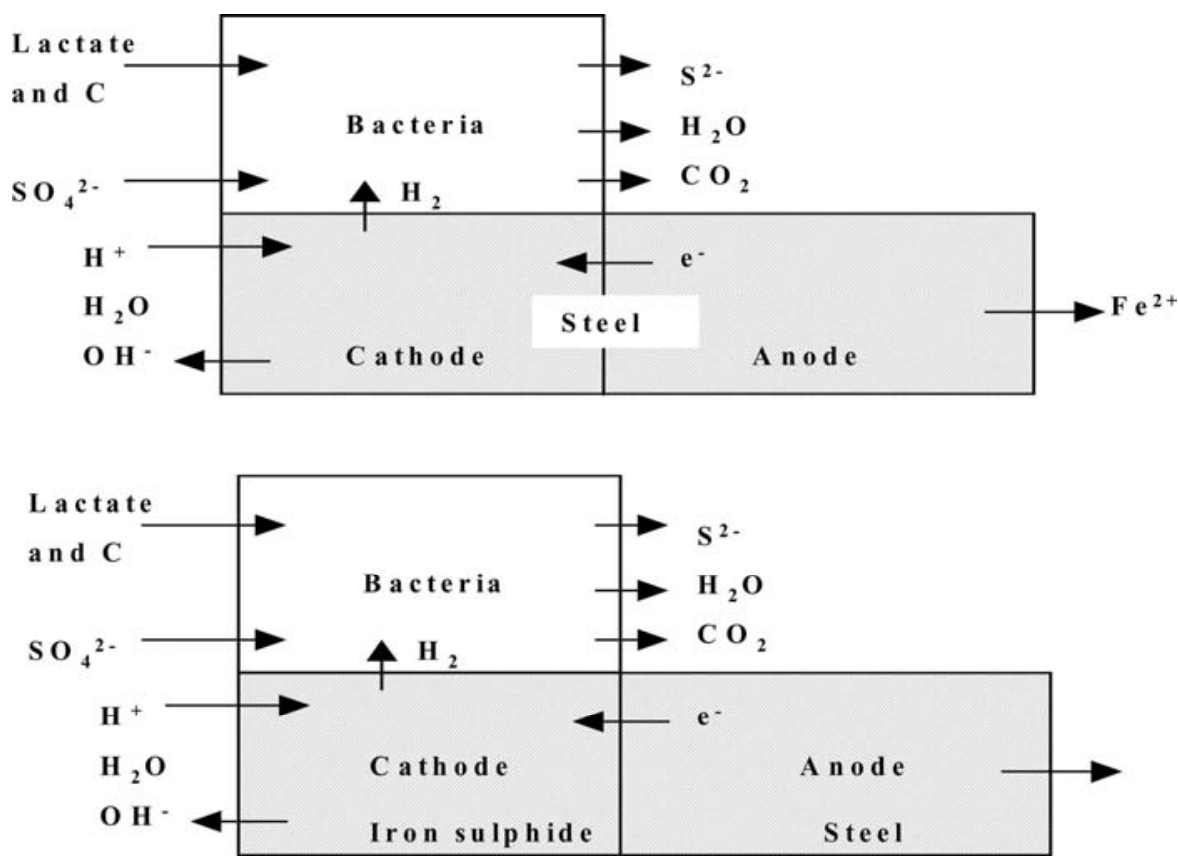

FIG. 10. Schematic presentation of the classical mechanism (top) and the adapted mechanism of cathodic depolarization where ferrous sulphide is the cathode (bottom) (Bro"zel \& Cloete 1989; Borenstein 1994).

anaerobic conditions and at low $\mathrm{pH}$ values, where the hydrogen sulphides may be unbuffered or where the acidity may be due to organic acids, hydrogen sulphide will corrode iron with the release of hydrogen (De Bruyn 1992). Hydrogen sulphide may be spontaneously or biologically oxidised to elemental sulphur in the presence of oxygen, or anaerobically by biological photosynthetic oxidation by, for example, green and purple sulphur bacteria. Elemental sulphur is corrosive to mild steel under aerobic as well as anaerobic conditions (De Bruyn 1992). Mercaptans produced by a variety of organisms are also corrosive to certain materials (Iverson 1987).

\section{The Role of Hydrogen-Producing Bacteria in Corrosion}

Damage to metals results from entry of atomic hydrogen into the lattice. This may result in embrittlement, with loss of ductility and tensile strength, crack propagation, or stress corrosion crackling. Hydrogen-induced failure of metals has been recognized as a serious problem because of the potential for catastrophic failure (Ford \& Mitchell 1990).

The role of bacteria and other microorganisms in the hydrogen embrittlement process is not understood (Ford \& Mitchell 1990). Because the production of atomic hydrogen has been identified as a major factor in hydrogen damage of metals, it can be assumed that microbial transformations involving the production of hydrogen would be relevant. Furthermore, the presence of microbially produced sulphide increases significantly the probability that metals will absorb hydrogen.

Under different nutrient regimes, SRB, which are traditionally thought to consume hydrogen and hence cathodically depolarise a metal will in fact generate hydrogen (Figure 11).

\section{The Role of Reduced Phosphorous Compounds on Corrosion}

Phosphate is similar in structure to sulphate, the phosphorous atom having a redox state of $+\mathrm{V}$ (Brözel 1990). Desulfovibrio desulfuricans produced colloidal iron phosphate in yeast extract both in the presence of steel and a hydrogen atmosphere and phosphate increase the rate of corrosion of carbon steel in the presence of this organism, especially when the organic energy 
source was the limiting substrate (Brözel \& Cloete 1989). Because reduced phosphorous is highly reactive, it could contribute to corrosion of iron. However, its production by SRB has not been conclusively shown (Brözel 1990).

According to Iverson (1987), previous reports by many investigators stated that the rate of anaerobic corrosion was related to the ferrous ion concentration in the medium; the greater the concentration the greater the corrosion rate. Extensive corrosion of steel was obtained under anaerobic conditions in a filtrate of a marine culture of Desulfovibrio from which all the free sulphide ions were removed by addition of ferrous ions and the resulting iron sulphide and the bacterial cells were removed by Seitz filtration (Iverson 1987). These results indicated that neither iron sulphide nor sulphide ions, nor bacterial cell were necessary for the corrosion. Furthermore, the main corrosion product was again found to be amorphous iron phosphide and further results indicated that the corrosive agent was a volatile phosphorus compound produced by the SRB. The stimulation of corrosion by ferrous ions was due to the prevention of iron sulphide film formation by the precipitation of sulphide ions as bulk iron sulphide in solution, thereby permitting the corrosive phosphorus compound to come into contact with the bare iron surface and initiate corrosion (Iverson 1987). The breakdown of a performed iron sulphide film would permit the phosphorus compound access to the iron surface and initiate corrosion (Iverson 1987).

Several authors have emphasised the importance of dissolved oxygen on the SRB-related corrosion of ferrous metal and alloys

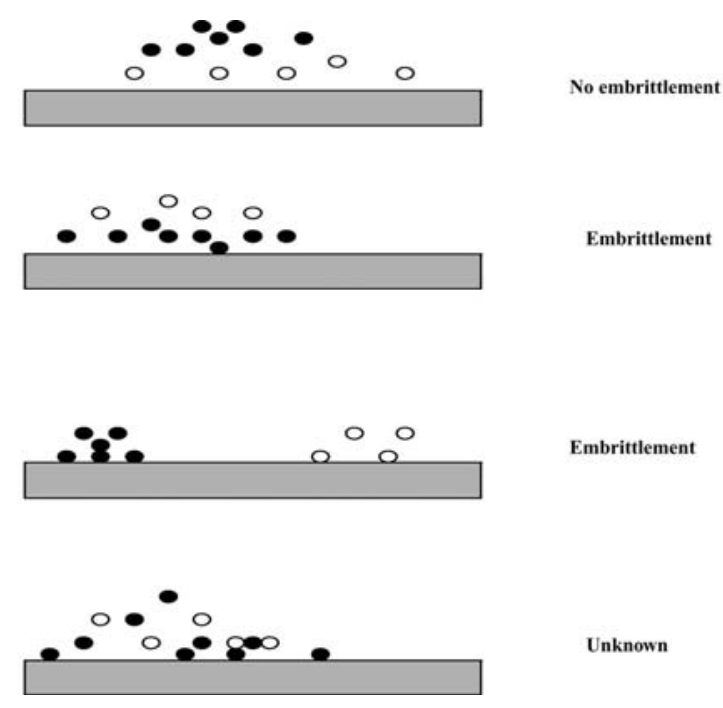

FIG. 11. Competition between hydrogen-consuming, hydrogen-producing bacteria, and hydrogen-absorbing metals (Ford \& Mitchell 1990).

(Lee et al. 1995). Accelerated corrosion rates have been observed when iron, corroded by SRB, is exposed to intermittent aerobicanaerobic environments (Lee et al. 1995). It was showed that corrosion rates of mild steel increased substantially when after several days' incubation anaerobic cultures were sparged with air and it was suggested that environmental factors, most notably oxygenation, are central to determining the rate and extent of SRB related corrosion (Lee et al. 1995). The accelerated corrosion rate with dissolved oxygen in the presence of SRB can be attributed to the combined effect of acid-volatile-sulphides and non-acid-volatile sulphide (Lee et al. 1995).

Figure 12 summarizes the processes contributing to the corrosion of mild steel in adjacent oxic and anoxic biofilms (Lee et al. 1995). There are more processes involved in the aerobic/anaerobic system than in a totally anaerobic system. In addition to the ferrous sulphide production, the oxygen uptake in the aerobic system needs to be addressed to explain the pronounced effect of dissolved oxygen on SRB-enhanced corrosion. The oxygen consumption in the aerobic system can be attributed to the following processes: (1) aerobic respiration processes; (2) microbial and chemical reoxidation of sulphides and ferro compounds (e.g., $\mathrm{Fe}^{2+}, \mathrm{FeS}, \mathrm{FeS}_{2}$ and $\mathrm{S}^{0}$ ); and (3) cathodic depolarisation process (Lee et al. 1995).

According to Barton (1997), Hardy and Brown (1984) exposed a sheet of mild steel to a growing culture of a marine Desulfovibrio sp. under controlled conditions of anoxia and noted the formation of a non-homogeneous black gelatinous biofilm with a number of small tubercles. A low rate of corrosion was reported. After completion of the growth phase, the vessel was subjected to short pulses of air and during these it was noted that the corrosion rate showed an instantaneous 90 -fold increase to a value of $650 \mu \mathrm{m} . \mathrm{y}^{-1}$. The nature of the corrosion was pitting, directly associated with the tubercles. The design of this experiment clearly excludes the possibility of oxygen having its effect on the growth of the SRB, or on the initial stages of biofilm development and the accumulation of ferrous sulphide corrosion products. 
The initial corrosion behavior of mild steel under an aerobic/ anaerobic biofilm has been systematically studied by changing the bulk dissolve oxygen concentrations at constant substrate loading rate (Lee et al. 1995). The mixed population biofilms were heterogeneous (or "patchy") with respect to the spatial distribution of microbial species. In anaerobic microniches SRB were found to proliferate even when dissolved oxygen penetrated the entire biofilm at other locations. These findings show that during the initial stage of biofilm accumulation aerobic corrosion was evident and the corrosion rate decreased with time. However, during later stages of biofilm accumulation, SRB-enhanced corrosion began as a localised attack, which was eventually propagated over the entire steel surface (Lee et al. 1995). The influence of bulk DO concentration on the second-stage SRB-related corrosion is significant. At low bulk DO concentration, several sulphide-attacked areas were observed in the form of small, shallow pits. At high bulk DO concentration, initial sulphide attack was concentrated at one spot. Consequently, large, deep pits were observed within the sulphide-attacked areas. These results suggest that it is likely to be the patchiness of the SRB biofilm which is responsible for the observed localized attack, rather than any special features of either the anodic or cathodic reactions within the electrochemical corrosion cell (Lee et al. 1995).

On the basis of these studies, it was hypothesized that SRB and their sulphide and sulphur corrosion products stimulate corrosion cathodically by acting as electron carriers between the metal surface and the oxic interface within the biofilm (Table 2).

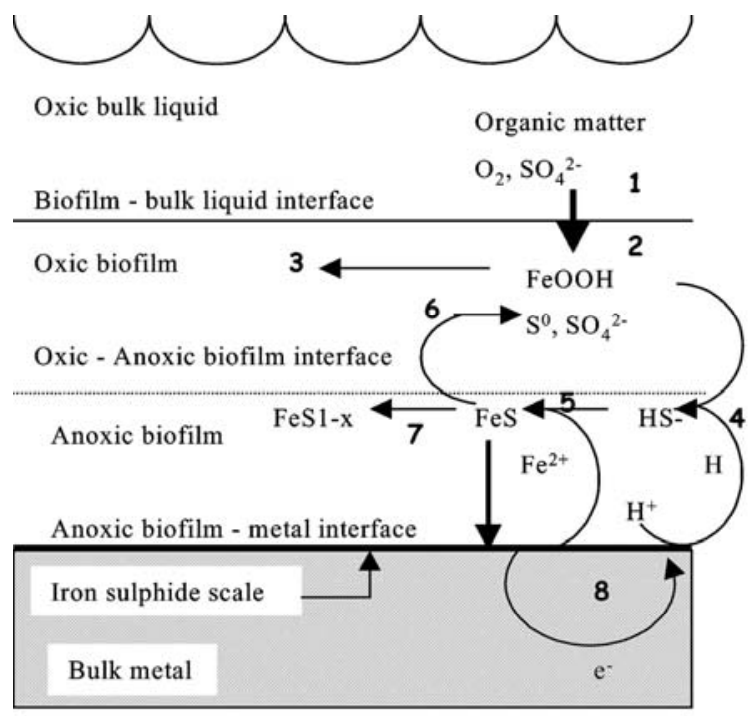

1 Mass transport process
2 Anaerobic metabolic
processes
3 Ferric hydroxide
precipitation
4 General anaerobic
metabolic,
sulphate reducing
processes
5 Ferrous sulphide
precipitation
6 Sulphide oxidation
processes
7 Pyrite formation process
8 Electrochemical corrosion
process

FIG. 12. Schematic diagram of transport and transformation processes contributing to corrosion of mild steel in aerobic/anaerobic biofilm (Lee et al. 1995). 
TABLE 2

Organisms involved in the corrosion of iron as well as other metals (De Bruyn 1992)

\begin{tabular}{|c|c|c|}
\hline Group of organisms & Examples of organisms & Corrosion mechanisms \\
\hline Sulphur oxidising & $\begin{array}{l}\text { Thiobacillus thiooxidans } \\
\text { T. concretivorus }\end{array}$ & Production of sulphuric acid \\
\hline Iron bacteria & $\begin{array}{l}\text { Gallionella } \\
\text { Sphaerotilus } \\
\text { Crenothrix } \\
\text { Lepptothrix } \\
\text { Clonothrix } \\
\text { Lieskeella }\end{array}$ & $\begin{array}{l}\text { Oxidation of ferrous to ferric ions which results } \\
\text { in the deposition of ferric hydroxide (tubercle } \\
\text { formation) }\end{array}$ \\
\hline Hydrogen consuming & $\begin{array}{l}\text { Sulphate reducers } \\
\text { Methanogens }\end{array}$ & Cathodic depolarization \\
\hline Hydrogen producing & $\begin{array}{l}\text { Sulphate reducers } \\
\text { Clostridium }\end{array}$ & Hydrogen embrittlement \\
\hline Thermophillic & $\begin{array}{l}\text { Desulfovibrio thermophilus } \\
\text { Thermodesulfobacterium } \\
\text { Pyrodictium } \\
\text { Sulfolobus }\end{array}$ & $\begin{array}{l}\text { Cathodic depolarization } \\
\mathrm{H}_{2} \mathrm{O} \text { production } \\
\text { Cathodic depolarization } \\
\text { Acid production }\end{array}$ \\
\hline Miscellaneous & Pseudomonas & $\begin{array}{l}\text { Reduction of ferric to soluble ferrous iron, slime } \\
\text { and acid production, formation of oxygen } \\
\text { concentration cells }\end{array}$ \\
\hline & $\begin{array}{l}\text { Lactobacillus delbrueckii } \\
\text { Cellulose degrading bacteria } \\
\text { Clostridium }\end{array}$ & $\begin{array}{l}\text { Organic acid production } \\
\text { Acetic and butyric acid production }\end{array}$ \\
\hline Fungi & $\begin{array}{l}\text { Cladosporium resinae } \\
\text { Aspergillus niger } \\
\text { A. amstelodami } \\
\text { Penicillium cyclopium } \\
\text { P. brevicompactum }\end{array}$ & $\begin{array}{l}\text { Carboxylic acid production } \\
\text { Acid production } \\
\text { Concentration cell formation }\end{array}$ \\
\hline
\end{tabular}

\section{CONCLUSIONS}

It is evident that many biotic and abiotic (physical and chemical) factors have demonstrable effects on bacterial attachment to solid surfaces, including physical factors such as: hydrodynamic forces; shear effects; substratum roughness; some physicochemical and thermodynamic factors and gravity that promotes the attachment of nonmotile bacteria to surfaces. These and many other factors, such as substratum chemistry, surface free energy, and solution ionic strength, are recognized as vital in some way to biofilm formation and development. An understanding of the activities of microorganisms on surfaces and an insight into the influence of certain surface features are critical to the control of biocorrosion and other biologically mediated processes.

The following key questions require answers in any attempt to describe mechanisms underlying microbial corrosion:

- Are microorganisms involved in the creation of an electrochemical cell, or in its continued functioning over a prolonged period?

- Do they affect principally the anodic or cathodic reaction?

- Is the mechanism direct or indirect?

- What is the identity of the cathodic electron acceptor, particularly under anoxic conditions?

- Is the influence of biofilm growth primarily metabolic through the combined action of organisms present as a consortium, or physical through the development of diffusion gradients and microenvironments?

- Can pitting corrosion be the consequence of colonial growth or development of a patchy biofilm?

- Do the corrosion products themselves have an influence on the nature and extent of any further corrosion?

To understand biocorrosion, it is important to integrate chemical and physical phenomena with microbial physiology. Investigation of microbial parameters, such as the identity of the microorganisms and their spatial distribution, for example, by fluorescently 
labelled 16S rRNA probes, is in this context a key factor. However, data on the microbial activity and the chemical situation within the biofilm (investigated via micro-electrodes) have more relevance toward the corrosion problem than knowing which bacteria are present. Together with this, electrochemical phenomena on the metal surface have to be quantified and interrelated to have a global view on the complex situation.

\section{REFERENCES}

Absolom, D.R. Lamberti., F.Y., Policova, Z., Zingg., W., Van Oss, C.J., and Neumann, A.W. 1983. Surface thermodynamics of bacterial adhesion. Appl. Environ. Microbiol. 46, 90-97.

Atlas, R.M. 1984. Diversity of microbial communities. Adv. Microbiol. Ecol. 7, 1-47.

Atlas, R.M., and Bartha, R. 1987a. Evolution and structure of microbial communities. In: Microbial Ecology: Fundamentals and Applications. 2nd edn, Menlo Park, CA: Benjamin/Cummings.

Atlas, R.M., and Bartha, R. 1987b. Microorganisms in their natural habitats: air, water, and soil microbiology. In: Microbial Ecology: Fundamentals and Applications. 2nd edn, Menlo Park, CA: Benjamin/Cummings.

Barton, L.L. 1997. Sulphate-reducing Bacteria. International workshop on Industrial Biofouling and Biocorrosion. Mulheim, Germany, September, 1997.

Boopathy, R., and Daniels, L. 1991. Effect of pH on anaerobic mild steel corrosion by methanogenic bacteria. Appl. Environ. Microbiol. 57(7), $2104-2108$.

Booth, G.H., Elford, L., and Wakerley, D.S. 1968. Corrosion of mild steel by sulphate-reducing bacteria: An alternative mechanism. British Corrosion J. 3, 242-245.

Booth, G.H., and Tiller, A.K. 1960. Polarization studies of mild steel in cultures of sulfate-reducing bacteria. Trans Faraday Soc. 56, $1689-1696$.

Borenstein, S.W. 1994. Microbiologically influenced corrosion handbook. Cambridge, England: Woodhead Publishing Limited.

Brandis, A., and Thauer, R.K. 1981. Growth of Desulfovibrio species on hydrogen and sulphate as sole energy source. J. General Microbiol. 126, $249-252$.

Brözel, V. S. (1990). Aspects of Bacterial Biofouling Control in Water Systems. MSc Thesis, University of Pretoria, S. Africa.

Brözel, V.S. 1990. Aspects of bacterial biofouling control in water systems. M.Sc Thesis. University of Pretoria, Pretoria, South Africa.

Brözel, V.S., and Cloete, T.E. 1989. The role of sulphate-reducing bacteria in microbial induced corrosion. Paper SA.11/12/89: 30-36.

Bryant, R.D., Jansen, W., Boivin, J., Laishley, E.J., and Costen, J.W. 1991. Effect of hydrogenase and mixed sulfate-reducing bacterial populations on the corrosion of steel. Appl. Environ. Microbiol. 57, 2804-2809.

Bryant, R.D., and Laishley, E.J. 1989. The role of hydrogenase in anaerobic biocorrosion. Canadian J. Microbiol. 36, $259-264$.

Bryers. J.D. 1988. Modelling biofilm accumulation. In: Physiological models in Microbiology. Vol. II, ed. M.J. Bazin \& J.I. Prosser. Boca Raton, FL: CRC Press.

Caldwell, D.E., and Lawrence,J.R. 1989.Microbial growth andbehaviour within surface microenvironments. Recent Advances in Microbial Ecology: Proc. 5th Int. Symp. on Microbial Ecology. Kyoto, Japan.

Characklis, W.G. 1983. Process analysis in microbial systems: Biofilms as a case study. In: Mathematics in Microbiology, ed. M. Bazin. London: Academic Press. Costerton, J.W., Irwin, R.T., and Cheng, K.J. 1981. The bacterial glycocalyx in nature and disease. Ann. Rev. Microbiol. 35, $299-324$.

Costerton, J.W., Nickel, J.C., and Ladd, T.I. 1986. Suitable methods for the comparative study of free-living and surface-associated bacterial populations In: Bacteria in Nature, Vol. 2, eds. J. S. Poindexter \& E. R. Leadbetter. New York: Plenum Press.

Costerton, J.W., and Lappin-Scott, H.M. 1989. Behaviour of bacteriain biofilms. ASM News 55, 650-654.

Costerton, J.W., Cheng, K.J., Geesey, G.G., Ladd, T.I., Nickel, J.C., Dasgupta, M., and Marrie, T.J. 1987. Bacterial biofilms in nature and disease. Ann. Rev. Microbiol. 41, 435-464.

De Bruyn, E. 1992. Microbial ecology of sulphide-producing bacteria in water cooling systems. PhD Thesis. University of Pretoria. South Africa.

Dowling, N.J.E., Brooks, S.A., Phelps, T.J., and White, D.C. 1992. Effects of selection and fate of substrates supplied to anaerobic bacteria involved in the corrosion of pipe-line steel. J. Industrial Microbiol. 10, 207-215.

Dvorak, D.H., Hedin, R.S., Edenborn, H.M., and McIntire, P.E. 1991. Treatment of metal-contaminated water using bacterial sulfate reduction: results from pilot-scale reactors, Proceedings of the 1991 National Meeting of the American Society for surface Mining and Reclamation, Durango, Colorado, May 14-17, 1991, American Society for surface Mining and Reclamation, Princeton, W.V, 1, 109-122.

Fauque, G., Peck Jr, H.D., Moura, J.J.G., Huynh, B.H., Berlier, Y., Der Var-tanian, D.V., Teixeira, M., Przbyla, A.E., Lespinat, P.A., Moura, I., and LeGall, J. 1988. The three classes of hydrogenases from sulfate-reducing bacteria of the genus Desulfovibrio. FEMS Microbiology Review 54, $299-344$.

Ford, T., and Mitchell, R. 1990. The ecology of microbial corrosion. Advances in Microbial Ecol. 11, 231-262.

Grant, W.D., and Long, P.E. 1981. The aquatic environment. In: Environmental Microbiology. New York: John Wiley.

Hamilton, W.A. 1987. Biofilms: Microbial interactions and metabolic activities. In: Ecology of Microbial Communities. eds M. Fletcher, T.R.G. Gray \& J.G. Jones, Oxford University Press.

Hamilton, W.A. 1985. Sulphate reducing bacteria and anaerobic corrosion. Ann. Rev. Microbiol. 39, 195-217.

Hardy, J.A. 1983. Utilisation of cathodic hydrogen by sulphate-reducing bacteria. British Corrosion J. 18(4), 190-193.

Hardy, J.A., and Brown,J.1984. The corrosion ofmild steelbybiogenic sulphide films exposed to air. Corrosion 40, 650-654.

Harvey, R.W., and Young, L.Y. 1980. Enumeration of particle-bound and unattached respiring bacteria in the salt marsh environment. Appl. Environ. Microbiol. $40,156-160$.

Hobbie, J.E., and Fletcher, M.M. 1988. The aquatic environment. In: Microorganisms in Action: Concepts and Applications in Microbial Ecology. eds J. M. Lynch \& J. E. Hobbie. Oxford: Blackwell Scientific.

Iverson, W.P. 1987. Microbial corrosion of metals. Advances in Applied Microbiology 32, 1-36.

Joubert, W.A. 1987. Isolation and characterisation of saccharolytic sulfate-reducing bacteria from an anaerobic hybrid digester. PhD Thesis. University of the Orange Free State, Bloemfontein, South Africa.

Kirchman, D., and Mitchell, R. 1982. Contribution of particle-bound bacteria to total microheterotrophic activity in five ponds and two marshes. Appl. Environ. Microbiol. 43, 200-209.

Kjelleberg, S., Humphrey, B.A., and Marshall, K.C. 1982. Effect of interfaces on small, starved marine bacteria. Appl. Environ. Microbiol. 43 , $1166-1172$.

Lawrence, J.R., Delaquis, P.J., Korber, D.R., and Caldwell, D.E. 1987. Behaviour of Pseudomonas fluorescents within the hydrodynamic boundary layers of surface microenvironments. Microbial Ecol. 14, 1-14.

Lee, W., and Characklis, W.G. 1990. Corrosion of mild steel under anaerobic biofilm. Corrosion 49(3), 186-199.

Lee, W., Lewandowski, Z., Nielsen, P.H., and Hamilton, W.A. 1995. Role of sulfate-reducing bacteria in corrosion of mild steel: A review. Biofouling 8, 165194.

Lewin, R. 1984. Microbial adhesion is a sticky problem. Science. 224, 375-377. 
Little, B., Wagner, P., Hart, K., Ray, R., and Lavoie, D. 1997. International workshop on Industrial Biofouling and Biocorrosion. Mulheim, Germany, September, 1997.

Marshall, K.C. (ed.) (1984). Microbial Adhesion and Aggregation. Springer Verlag, Berlin.

Nedwell, D.B., and Banat, I.M. 1981. Hydrogen as an electron donor for sulphate-reducing bacteriainslurriesofsalt marsh sediments.Microbial Ecology 7, 605313.

Odom, J.M. 1990. Industrial and environmental concerns with sulphate-reducing bacteria. International workshop on Industrial Biofouling and Biocorrosion. Mulheim, Germany, September, 1997.

Pankhania, I.P., Moosavi, A.N., and Hamilton, W.A. 1986. Utilization of ca-thodic hydrogen by Desulfovibrio vulgaris. J. General Microbiol. 132, $3357-3365$.

Pavlostathis, S.G., Miller, T.L., and Wolin, M.J. 1990. Cellulose fermentation by continuous cultures of Ruminoccus albus and methanobrevibacter smithii. Applied Microbiology and Biotechnology 5, 259-302.

Pfennig, N. (1984). Microbial behaviour in natural environments. In: The Microbe 1984 Part II. Procaryotes and Eukaryotes. Oxford University Press, Oxford.

Prescott, L.M., Harley, J.P., and Klein, D.A. 1990. Microbiology. Wm. C. Brown Publishers. United States of America.

Quatibi, A.I., Bories, A., and Garcia, J.L. 1990. Effects of sulphateon lactate and $\mathrm{C}_{2}-\mathrm{C}_{3}$-volatile fatty acid anaerobic degradation by mixed microbial culture. Antonie van Leeuwenhoek 58, 241-248.

Rutter, P.R., and Vincent, B. 1984. Physicochemical interactions of the substratum, microorganisms, and the fluid phase. In: Microbial Adhesion and Aggregation, ed. K. C. Marshall. Berlin: Springer Verlag.

Rutter, P.R., and Vincent, B. 1988. Attachment mechanisms in the surface growth of microorganisms. In: Physiological Models in Microbiology. Vo 1 II. Eds M. J. Bazin and J.J. Presser, CRC Press, Boca Raton, Florida.

Speece, R.E. 1996. Anaerobic Biotechnology. Nashville, TN: Archae Press.

Sutherland, I.W. 1985. Biosynthesis and composition of Gram-negative bacterial extracellular and wall polysaccharides. Ann. Rev. Microbiol. 39, $243-270$.

Valeur, A., Tunlid, A., and Odham, G. 1988. Differences in lipid composition between free-living and initially adhered cells of a Gram-negative bacterium. Arch. Microbiol. 149, 521-526.

VanDemark, P.J., and Batzing, B.L. 1987. The Microbes. An Introduction to their Nature and Importance. Menlo Park, CA: The Benjamin/Cummings Publishing Company Inc.

Van Loosdrecht, M.C.M., Lyklema, J., Norde, W., and Zehnder, A.J.B. 1990. Influence of interfaces on microbial activity. Microbiol. Rev. 54, $75-87$.

Von Holy, A. 1985. Microbial Corrosion. International workshop on Industrial Biofouling and Biocorrosion. Mulheim, Germany, September, 1997.

Von Holy, A. 1987. New approaches to microbiologically induced corrosion. Water Sewage and Effluent 39-44.

Von Wolzogen Ku"hr, C.A.H., and Van der Vlugt, L.S. 1934. Graphication of cast iron as an electrochemical process in anaerobic soils. Water 16, $147-165$.

Whitfield, C. 1988. Bacterial extracellular polysaccharides. Can J. Microbiol. 34, 425-420.

Wolfaardt, G.M. 1990. Technologies for studying biofouling and aspects influencing biofouling in industrial water systems. M.Sc. thesis, University of Pretoria, Pretoria, South Africa.

Wolfaardt, G.M., and Cloete, T.E. 1992. The effect of some environmental parameters on surface colonization by microorganisms. Water Research $26,527-537$. Widdel, F., and Pfennig, N. 1982. Studies on dissimilatory sulfate-reducing bacteria that decompose fatty acids. II. Incomplete oxidation of propionate by Desulfobulbus gen. Nov. sp. Nov. Archives of Microbiol. 131, 360-365.

Zdyb, L. 1999. Microbial sulfate reduction as a method of passive treatment of acid mine drainage using undefined carbon sources. M.Sc Thesis, University of Pretoria, South Africa. 
